www.volsu.ru

DOI: http://doi.org/10.15688/nav.jvolsu.2018.1.3

UDC 903' $1: 726$

LBC 63.442-427.7

\title{
DIAGONAL BURIALS AS A MARKER OF SUCCESSION OF SARMATIAN CULTURES IN THE FIRST CENTURIES AD ${ }^{1}$
}

\author{
Mariya A. Balabanova \\ Volgograd State University, Volgograd, Russian Federation \\ Mikhail V. Krivosheev \\ Volgograd State University, Volgograd, Russian Federation
}

\begin{abstract}
The paper is devoted to studying diagonal funerary complexes as markers of Sarmatian cultures succession in the first centuries AD. The research is based on the analysis of the Middle Sarmatian and Late Sarmatian diagonal burial rite and on the anthropological materials. We have used 53 diagonal archaeological complexes of the Late Sarmatian time and the craniological series of 42 Middle Sarmatian sculls and 24 Late Sarmatian sculls.

The research results have show that the problem of succession is connected with the preservation of the rite, and the transformation is connected with the modification of certain elements of material culture.

The anthropological materials of the diagonal burials demonstrate the absence of a uniform craniological complex in this group. We can clearly distinguish the type of long-headed Caucasians that prevailed in the Late Sarmatian period and the brachicranian Caucasoid type with a weakened horizontal profiling of the facial structures that is characteristic of the Early Sarmatian population.

The intergroup comparison of the craniological series has shown a significant similarity of the male series without deformation of the Middle Sarmatian and Late Sarmatian times and a sharp contrast between them and the group with deformation of the late Sarmatian time. In addition, the clearly marked mixed Europoid-Mongoloid variant, both among the "diagonal burial population" and the entire Middle Sarmatian sample, allows us talking confidently about the eastern (South Siberian) migrations, which could be a source of cultural innovations and new anthropological components.

The comprehensive analysis of archaeological and anthropological materials of diagonal burials of the first centuries $\mathrm{AD}$ demonstrates extremely interesting processes of interaction of the different nomadic groups. The diagonal rite was brought to the Sarmatians by the Middle Sarmatian culture in the $1^{\text {st }}$ century AD and, probably, adopted by the local population. In the process of formation of the Late Sarmatian culture in the second half of the $2^{\text {nd }}$ - beginning of the $3^{\text {rd }}$ century AD diagonal burials had still been used, which was associated with a powerful Middle Sarmatian substratum. However, this rite was adopted by the Late Sarmatian population as well.

Key words: diagonal type of burial, burial rite, Middle Sarmatian time, Late Sarmatian time, custom of artificial deformation of the skull, ware complex, succession.
\end{abstract}

Citation. Balabanova M.A., Krivosheev M.V., 2018. Diagonal Burials as a Marker of Succession of Sarmatian Cultures in the First Centuries AD. The Lower Volga Archaeological Bulletin, vol. 17, no. 1, pp. 50-75. (in Russian).

УДК 903'1:726

ББК $63.442-427.7$

\section{ДИАГОНАЛЬНЫЕ ПОГРЕБЕНИЯ КАК МАРКЕР ПРЕЕМСТВЕННОСТИ В САРМАТСКИХ КУЛЬТУРАХ В ПЕРВЫЕ ВЕКА НАШЕЙ ЭРЫ ${ }^{1}$}

\author{
Мария Афанасьевна Балабанова \\ Волгоградский государственный университет, г. Волгоград, Российская Федерация \\ Михаил Васильевич Кривошеев \\ Волгоградский государственный университет, г. Волгоград, Российская Федерация
}


Аннотация. Статья посвящена диагональным погребальным комплексам как маркерам преемственности сарматских культур в первые века нашей эры. Исследование основано на анализе диагонального обряда погребения и антропологического материала среднесарматского и позднесарматского времени. Для исследования использованы 53 диагональных археологических комплекса позднесарматского времени и краниологические серии: 42 черепа среднесарматского времени; 24 черепа позднесарматского времени.

Как показали результаты исследования археологических комплексов, проблема преемственности связана с сохранением обряда, а трансформация - с изменением некоторых элементов материальной культуры.

Антропологический материал диагональных погребений демонстрирует отсутствие в этой группе единого краниологического комплекса. Четко выделяется тип длинноголовых европеоидов, который преобладает в позднесарматское время, и брахикранный европеоидный тип с ослабленной горизонтальной профилировкой лицевых структур, характерный для раннесарматского населения.

Межгрупповое сопоставление краниологических серий показало большое сходство мужских серий без деформации среднесарматского и позднесарматского времени и резкое отличие от них группы с деформацией позднесарматского времени. Кроме этого, четко выделенный смешанный европеоидно-монголоидный вариант как среди «диагональников», так и по всей среднесарматской выборке, позволяет уверенно говорить о восточных (южносибирских) миграциях, которые могли являться источником культурных новаций и новых антропологических компонентов.

Комплексный анализ археологических и антропологических материалов диагональных погребений первых веков демонстрирует крайне интересные процессы взаимодействия различных по своему происхождению групп кочевого населения. Диагональный обряд был принесен в сарматскую среду носителями среднесарматской культуры в I в. н.э. и, вероятно, воспринят местным населением предшествующей эпохи. В процессе формирования позднесарматской культуры во второй половине II - начале III в. н.э. диагональные погребения продолжали использоваться, что связано с мощным субстратным среднесарматским компонентом, однако этот обряд также воспринимался и пришлым позднесарматским населением.

Ключевые слова: диагональный тип захоронения, погребальный обряд, среднесарматское время, позднесарматское время, обычай искусственной деформации черепа, вещевой комплекс, преемственность.

Цитирование. Балабанова М. А., Кривошеев М. В., 2018. Диагональные погребения как маркер преемственности в сарматских культурах в первые века нашей эры // Нижневолжский археологический вестник. T. 17, № 1. C. 50-75.

\section{Постановка проблемы и история исследования}

Диагональными принято называть погребальные комплексы, в которых умерший человек был положен по диагонали широких прямоугольных и квадратных ям.

Традиция диагональных захоронений у кочевников южнорусских степей отмечается еще в памятниках савроматской культуры с V в. до н.э. И.П. Засецкая, изучив представительную выборку диагональных погребений, выделила среди них две хронологические группы: савроматского времени - VI - начала III в. до н.э. и сарматского - I в. до н.э. - III в. н.э. Данный обряд в I в. до н.э. - III в. н.э. она не отделяет от единой культуры, характеризующейся и иными конструкциями могил [Засецкая, 1974, с. 105-121]. А.С. Скрипкин, вслед за И.П. Засецкой, также выделяет две хронологические группы диагональных погребений: V-IV вв. до н.э. и I - первая половина
III в. н.э. Он предполагает, что время наибольшего распространения поздней группы диагональных погребений относится к I-II вв. н.э. и отмечает, что со II в. н.э., в позднесарматское время, данный обряд угасает и в первой половине III в. н.э. окончательно прекращает свое существование [Скрипкин, 1981; 1992; 1997a].

Ранняя группа памятников с диагональным положением умершего, относящаяся к савромато-раннепрохоровскому времени (V начало III в. до н.э.), немногочисленна и составляет 2,3\% савроматских памятников и 4,7 \% памятников IV-III вв. до н.э. Наибольший процент дают могильники Южного Приуралья (5,3 \%). Особенно часто такие погребения встречаются в могильниках верховьев Урала, низовий Илека и Узеней [Железчиков, 1994, с. $131 ; 1997$, с. 82]. В позднепрохоровскую эпоху - III-I вв. до н.э. этот признак практически не встречается [Скрипкин, 19976, с. 183]. 
Вторая хронологическая группа диагональных погребений стала ярким признаком среднесарматской археологической культуры с I в. н.э. (рис. 1) [Скрипкин, 1990, с. 184, 185, 218-219; 1992, с. 9-18; 1996, с. 166; Сергацков, 2000, с. 221-223; 2002, с. 94]. Диагональное положение костяка в комплексах среднесарматских памятников встречается более чем в 16,0 \% погребений. Распределение этого признака по различным регионам сильно разнится. Причем в западных регионах он встречается редко: в Прикубанье - 0,68 \%; на Нижнем Дону $-7,84$ \%. Наибольший процент встречаемости диагональных захоронений среднесарматской культуры отмечен в восточном ареале: в могильниках Южного Приуралья он достигает $36,19 \%$; в Заволжье $28,21 \%$. Что касается Волго-Донского междуречья, то в северной его части таких памятников $-18,75 \%$, а в южной $-13,85 \%$. Достаточно большое количество их и в могильниках Правобережья Волги - 25,81 \% [Сергацков, 2002, с. 94; Мошкова, 2004а, с. 22].

На раннем этапе позднесарматской культуры традиция диагональных захоронений продолжает существовать, но постепенно угасает. На всей территории распространения позднесарматских памятников диагональных погребений насчитывается до 5,46 \%. В различных районах Нижнего Поволжья диагональные захоронения составляют от 6 до $11 \%$ (рис. 2) [Скрипкин, 1984, с. 65-67; 1990, с. 184, $185,218-219 ; 1992$, c. $9-18 ; 1996$, c. 166; 1997a, c. 63-77; Сергацков, 2000, с. 221-223; Кривошеев, 2005, с. 123; Мошкова, 2009, с. 88].

В предлагаемой работе особый интерес уделен поздней группе диагональных погребений I - первой половины III в. н.э. [Скрипкин, 1992, с. 11].

Круг проблем, связанных с диагональными захоронениями, включает в себя несколько аспектов: хронология диагональных погребений; поиски истоков этого оригинального погребального обряда и его семантика; этническая интерпретация данной группы сарматских захоронений; проблема преемственности культурных традиций и группы населения, практикующего этот обряд. Если первые три проблемы в той или иной степени освещены в научной литературе, то последняя проблема ставится впервые в данной работе.
Вопросы хронологии сарматских диагональных погребений наиболее детально проработаны в трудах А.С. Скрипкина. Им было установлено, что погребальный инвентарь из этой группы памятников Поволжья и Нижнего Дона позволяет датировать их не ранее I в. н.э. [Скрипкин, 1992, с. 14]. Наибольшее количество диагональных погребений приходится на I - начало II в. н.э. Диагональные погребения, датируемые второй половиной II - началом III в. н.э., приобретают некоторые черты позднесарматской культуры: северная ориентировка погребенных, искусственная деформация черепа, некоторые типы вещей, например кубические курильницы, мечи без металлического навершия и перекрестия и др. (рис. 3) [Скрипкин, 1984, с. 67; Сергацков, 2000, c. 215; Кривошеев, 2005, с. 173-177]. В период становления позднесарматской культуры вторая половина II в. н.э. - начало III в. н.э. вместе с диагональными погребениями существуют и переходные типы погребений, в которых утрачено диагональное положение костяка, но иногда сохраняется некоторое отклонение от стенок ямы [Скрипкин, 1984, с. 67; Кривошеев, 2005, с. 176-177].

В свое время наиболее дискуссионной среди ученых являлась проблема этнической принадлежности диагональных погребений. Открыл дискуссию К.Ф. Смирнов, который предположил, что сарматские диагональные захоронения были оставлены роксоланами [Смирнов, 1948, с. 213-219]. М.П. Абрамова не согласилась с такой версией, указав на несовпадение по времени диагональных погребений в Нижнем Поволжье с появлением роксолан по свидетельствам древних авторов [Абрамова, 1959, с. 59]. Б.Н. Граков также отрицал принадлежность диагональных погребений роксоланам, однако, специально он не аргументировал это высказывание [Граков, 1964, с. 239]. В.П. Шилов приписывал данный погребальный обряд иной этнической группе, нежели роксоланы, название которой до нас не дошло, а ее социальный статус в сарматском обществе был не высок, на что, по мнению В.П. Шилова, указывает «бедность» погребений. В.П. Шилов также считал, что нет никаких упоминаний в источниках о том, что роксоланы когда-либо населяли территорию Нижнего Поволжья, где сосредоточено наи- 
большее количество диагональных погребений [Шилов, 1959, с. 454-456]. К.Ф. Смирнову пришлось вследствие подобных возражений и накопления нового материала скорректировать свою точку зрения. Он расширил этническую принадлежность данного обряда, распространив ее на поволжских аланов и аорсов [Смирнов, 1959, с. 319]. Позднее К.Ф. Смирнов склонялся к идее, что диагональные погребения отражали религиозные представления сарматов и не являлись специфическим этническим признаком [Смирнов, 1974, с. $42-$ 43]. Выступая в печати с критикой по поводу роксоланской принадлежности диагональных погребений, И.П. Засецкая указала на то, что эта гипотеза не подкрепляется ни данными археологии, ни данными письменных источников. По ее мнению, в контексте всей среднесарматской культуры диагональные погребения могут характеризовать социальные и религиозные представления носителей данного погребального обряда и быть связаны с могущественным аорсским племенным союзом [Засецкая, 1974, с. 121].

А.С. Скрипкин, изучая многочисленный археологический материал с территории Азиатской Сарматии, считает невозможным относить диагональные погребения ни к роксоланам, ни к аорсам, так как этот обрядовый элемент господствует позднее наибольшей активности аорсского и роксоланского племенных союзов [Скрипкин, 1988, с. 129]. Автор считает, что распространение диагональных захоронений в волго-донских степях совпадает с первыми упоминаниями алан в письменных источниках [Скрипкин, 1988, c. $129 ; 1990$, с. 214-220]. Гипотеза аланской принадлежности диагональных погребений подкрепляется наличием значительного количества таких комплексов на Нижнем Дону и в Волго-Донском междуречье. На основе данных Иосифа Флавия об аланах: «...племя алан есть племя скифов, живущих вокруг Танаиса и Меотийского озера» (Иосиф Флавий, VII, 7 , 4), Нижний Дон и Волго-Донское междуречье можно определить как территорию локализации аланского политического центра. Таким образом, диагональный тип захоронений культурная новация, которая распространяется в волго-донских степях вместе с приходом сюда в первом веке нашей эры новой группы мигрантов [Скрипкин, 1997a, с. 73]. Вместе с этим возникает еще одна проблема, связанная с затруднениями при выяснении принадлежности диагональных погребений непосредственно аланам или же другим племенам, входившим в аланский племенной союз и выступающим на исторической арене под этнонимом племени гегемона (Аммиан Марцеллин, XXXI, 2, 13).

Сарматские диагональные захоронения содержат разнообразный и многочисленный инвентарь [Максимов, 1966, с. 112; Засецкая, 1974, с. 112-113; Смирнов, 1974, с. 42; Скрипкин, 1992, с. 11-14; Глухов, 2001, с. 263-266; 2005 , с. 100,101$]$. Несмотря на многообразие погребального инвентаря их нельзя сопоставить с известными богатыми среднесарматскими комплексами из могильников Октябрьский V, Дачи, Кобяково, Садовый, Пороги и др., где диагональный обряд не зафиксирован. Некоторые исследователи, проанализировавшие половозрастную структуру диагональных погребений, считают, что в них могла отразиться специфика профессиональной направленности отдельных групп сарматского общества: мужчин, как профессиональных воинов, а женщин, как «жриц» [Скрипкин, 1997a, с. 70; Копылов, Кузнецов, Янгулов, 1990, с. 19-21; Глухов, 2005, с. 101].

Интересно отметить, что анализ половозрастной структуры среднесарматских диагональных комплексов II Бережновского могильника как относительно полно раскопанного могильника показал, что преимущественно по такому обряду хоронили женщин. На 22 не ограбленные могилы с половозрастными определениями, проведенными антропологом, женских погребений - 17, а мужских - 5. Собственно детских могил нет. Все дети в погребениях сопровождали женские захоронения. Чаще укладывали детей рядом, но есть и довольно оригинальная могила, сооруженная в кургане 18, где по диагонали лежит женщина старческого возраста, а вдоль северо-восточной стенки лежал скелет ребенка 2-3 лет. По трем сторонам могилы были устроены подбои, в которых лежали дети от 2-3 лет до 67 лет (рис. 4) [Синицын, 1960, с. 33; Фирштейн, 1970 , с. 78 , табл. 1; Балабанова, 2000, с. 90]. Во всех мужских захоронениях II Бережновского могильника обнаружены элементы воо- 
ружения: кинжалы, мечи, колчан со стрелами и т. д. Таким образом, материалы II Бережновского могильника свидетельствуют о воинском характере мужских диагональных погребений.

\section{Проблема преемственности на археологических материалах диагональных комплексов I - первой половины III в. н.э.}

По поводу истоков диагонального обряда захоронения в первые века нашей эры существует точка зрения, согласно которой в I в. н.э. в памятниках среднесарматской культуры появляются ряд культурных новаций, которые связывают с возрождением традиций скифской эпохи: это короткие мечи с волютообразным навершием; лепная керамика, типологически близкая савроматской; увеличение процента целых зеркал в погребениях; округлые или прямоугольные каменные плиты; наличие высокостатусных женских погребений; звериный стиль; использование грунтовых блоков при строительстве курганов [Скрипкин, 1992, с. 2930; 1996, с. 166; Гутнов, 2001; Кривошеев, 2013]. Среди таких элементов, получивших новую жизнь в среднесарматское время, был и обряд положения погребенных по диагонали квадратной или широкой прямоугольной ямы [Скрипкин, 1992, с. 29]. Предположение о сохранении традиций скифо-савроматского времени, среди которых и диагональный обряд захоронения, на какой-либо территории на протяжении нескольких столетий, в период господства раннесарматской культуры, до сих пор не находит подтверждения. Нет археологических свидетельств истоков среднесарматской культуры в том сложившемся, какой она предстала в I в. н.э. в южнорусских степях [Скрипкин, 1992, с. 29-30].

Как отмечалось выше, диагональные погребения в среднесарматское время в I - первой половине II в. н.э. обнаружены в $16 \%$ могил. Они встречаются в памятниках Южного Приуралья, Нижнего Поволжья, Нижнего Дона, в Северном Причерноморье [Сергацков, 2002; Мошкова, 2004б; Скрипкин, 1997а; Костенко, 1993]. Этот обряд продолжает существовать и на начальном этапе позднесарматской культуры [Скрипкин, 1984; 1997а; Кривошеев, 2010].
С приходом новой волны кочевников - носителей позднесарматской культуры с востока в середине II в. н.э. начинается новый этап в истории диагонального обряда.

В Южном Приуралье в середине II в. н.э. отмечается резкий переход от среднесарматской к позднесарматской археологической культуре, и преемственности между ними не наблюдается. Диагональные погребения, достаточно широко распространенные здесь в среднесарматский период (36,19 \%), в позднесарматское время представлены единичными находками, большинство из которых находится в северной части Южного Приуралья [Мошкова, 2004a, с. 33]. Отсутствие памятников синкретичного облика на этапе смены культур после середины II в. н.э. и выраженных примеров преемственности культурных традиций позволяет говорить о том, что позднесарматская культура представлена здесь в наиболее чистом виде [Малашев, 2013].

Зато в Нижнем Поволжье очень четко просматриваются резкие изменения погребального обряда на стыке средне- и позднесарматской культур. Стоит отметить, что позднесарматский археологический комплекс резко отличается от погребальных традиций среднесарматского времени: меняется основная ориентировка погребенных с южной на северную, используются погребальные сооружения с иными размерными пропорциями распространяются узкие прямоугольные ямы и подбои с узкими входными ямами, на ведущее место выходят традиции индивидуальных захоронений под собственными насыпями [Мошкова, 2009; Кривошеев, Скрипкин, 2011]. Около середины II в. н.э., вероятно, под влиянием позднесарматских кочевников наблюдается резкий отток носителей среднесарматской культуры с территории Заволжья в ВолгоДонское междуречье. Это отражается в изменении распределения погребальных конструкций в разных районах Нижнего Поволжья. В среднесарматское время диагональные погребения наиболее часто встречаются в Заволжье $(28,1 \%)$ и несколько реже в ВолгоДонском междуречье: в северной его части таких памятников $-18,75 \%$, а в южной $13,85 \%$. Что касается диагональных погребений позднесарматского времени второй половины II - начала III в. н.э., то подавляющее 
их большинство (86 \%) зафиксировано в Волго-Донском междуречье [Кривошеев, Скрипкин, 2011, с. 75].

На Нижнем Дону, вероятно, смена культур, связанная с появлением позднесарматских племен, происходит также быстро, как и в Южном Приуралье. Здесь проявления культурной преемственности, которые можно было бы зафиксировать на погребальном обряде, существуют крайне недолго и не составляют массового явления. Элементы позднесарматской культуры становятся ведущими здесь уже с середины II в. н.э. Диагональные погребения единичны и в них присутствуют обрядовые нормы позднесарматской культуры [Мошкова, 2004а; Кривошеев, 2005].

Именно диагональные погребения, как наиболее яркое явление в погребальном обряде среднесарматской культуры, можно использовать как маркер преемственности между средне- и позднесарматской культурами. Если связывать увеличение количества диагональных погребений в Волго-Донском междуречье с оттоком сюда среднесарматского населения из других районов после появления носителей позднесарматской культуры, то можно предположить, что во второй половине II в. н.э. в этом регионе складывается довольно мощная группировка носителей среднесарматской культуры. Вероятно, с этим связано длительное сохранение погребальных традиций среднесарматской культуры в Волго-Донском междуречье.

Во второй половине II - начале III в. н.э. преимущественно в междуречье Волги и Дона продолжают встречаться элементы, связанные с обычаями среднесарматской культуры, свидетельствующие о сохранении традиций предшествующей культуры у представителей этого населения. Среди таких обрядовых норм в первую очередь стоит говорить о широких прямоугольных ямах, диагональном положении и южной ориентировке погребенных. Основная масса диагональных погребений позднесарматского времени сосредоточена в южной части Волго-Донского междуречья, в правобережье Волги и в бассейне р. Есауловский Аксай. Немного меньше их в северной части Волго-Донского междуречья. Отдельные комплексы встречаются в Заволжье, на Нижнем Дону, в Южном Приуралье.
Однако уже с середины II в. н.э. в группе диагональных погребений наблюдаются изменения, вызванные взаимодействием с носителями позднесарматской культуры. С этого времени практически не встречается захоронений в квадратных ямах. При доминировании южной ориентировки в диагональных комплексах отмечаются случаи положения погребенных головой в северный сектор. Искусственная деформация черепов - элемент, принесенный позднесарматским населением, обнаружена почти на $30 \%$ черепов.

Редким явлением становится сооружение деревянных настилов на дне ям. Комплексы, где они встречены, датируются ближе к середине II в. н.э., что можно отнести к отголоскам среднесарматских традиций.

Среди жертвенной пищи в диагональных погребениях чаще всего встречаются кости ног барана. Однако если на среднесарматском этапе преимущественно клали ноги вместе с лопаткой, то в позднесарматское время лопатка встречена всего один раз. При этом встречаются задняя нога с тазовыми костями, что характерно для позднесарматской традиции [Скрипкин, 1984].

В позднесарматское время в диагональных захоронениях отмечаются серьезные изменения, демонстрирующие резкое изменение категорий и типов вещевого инвентаря, отличного от среднесарматского. Вооружение встречено в $28 \%$ погребений. Большая часть его представлена мечами и кинжалами. Среди них не встречено образцов с прямым перекрестием и кольцевым навершием, характерных для среднесарматского времени.

Среди зеркал, обнаруженных в позднесарматских диагональных погребениях, не встречаются типы, которые были популярны в среднесарматское время. Наиболее ранними являются зеркала-подвески с боковым ушком и умбоном в центре. Одно из них обнаружено в южной части Волго-Донского междуречья, в комплексе, который по подвязной лучковой фибуле 1-й серии 3-го варианта в сочетании с двуручным кувшином кавказского производства, вероятно, датируется около середины II в. н.э. (Терновский, кург. 14). Ко второй половине II в. н.э. относится погребение из северной части междуречья с аналогичным зеркалом (Племхоз, кург. 8) [Клепиков и др., 
2006, с. 170]. Находка из Племхоза запаздывает относительно основного времени существования этого типа около середины II в., что для северной части междуречья не уникально. В этом районе такое зеркало известно в комплексе, датируемом не ранее середины III в. н.э. [Гущина, Фирсов, 2000, с. 271-272, рис. 5,1$]$. В целом комплексы северной части Волго-Донского междуречья демонстрируют наиболее длительное сохранение среднесарматских традиций в ареале позднесарматской культуры [Сергацков, 2000, с. 225], что отражается как на обрядовых нормах, так и на вещевом материале.

Большинство зеркал представлено типом с боковым ушком и орнаментированной оборотной стороной. Чаще всего они встречаются в женских погребениях. В диагональных погребениях единственное зеркало с центральной петелькой, датируемое второй половиной II в. н.э. [Кривошеев, 2004], обнаружено в женском захоронении в кургане 55 могильника Старица.

Пружинные ножницы, появившись в среднесарматское время в единичных комплексах, максимальное распространение получили в позднесарматских погребениях второй половины II - первой половины III в. н.э. [Кривошеев, 2016]. В диагональных погребениях этого периода ножницы обнаружены в 6 комплекcax, что составило $11 \%$ от числа позднесарматских диагональных погребений.

Ярким примером стремительной трансформации традиций, произошедшей в середине II в. н.э., могут служить предметы и вещества, которые принято относить к кругу сакральных. Так, в позднесарматский период происходит отказ от помещения в могилу алебастровых сосудиков, которые часто сопровождают диагональные погребения среднесарматской эпохи. В позднесарматских диагональных захоронениях не встречаются цилиндрические курильницы, уступая место кубическим, которые становятся ведущим типом на протяжении всей позднесарматской культуры.

В позднесарматское время происходит отказ от еще одной традиции, которая имела широкое распространение в среднесарматской погребальной обрядности - это тайники, устроенные в дне или стенках могильных ям. Однако существуют единичные указания на то, что диагональные погребения позднесарматского времени имеют связь с традициями предшествующей культуры. В северной части Волго-Донского междуречья, в кургане 30 могильника Ютаевка, под тазом костяка, уложенного по диагонали ямы головой к югу, был устроен яма-тайник, в котором находился кованный медный котелок. Не исключено, что дата этого комплекса может заходить в III в. н.э., о чем свидетельствует найденная здесь железная пряжка с утолщением рамки в передней части [Скрипкин, 1973; Малашев, 2000, с. 209].

Так как диагональный обряд захоронения встречается в среднесарматское время и на раннем этапе позднесарматской культуры, анализ хронологических групп «диагональников» поможет ответить на вопрос об участии среднесарматских групп в формировании позднесарматского населения.

\section{Проблема преемственности}

\section{на антропологических материалах диагональных комплексов \\ I - первой половины III в. н.э.}

Некоторые антропологические особенности группы «диагональников» уже исследовались М.А. Балабановой и Е.В. Перервой ранее [Балабанова, 2002; Перерва, 2011].

В процессе краниологического исследования было выяснено, что серия «диагональников» в целом неоднородна и в ней преобладают два европеоидных морфотипа: длинноголовый и широкоголовый. Длинноголовый вариант предположительно можно идентифицировать с краниотипом мигрантов, носителей культурных новаций, а широкоголовый с раннесарматским субстратом. Согласно особенностям доно-аксайской и заволжской локальных групп, где преобладает тип длинноголовых европеоидов, связываемый с мигрантами, можно предположить пути их миграции на Нижнюю Волгу и Нижний Дон через Заволжье по Северному Каспию и по югу - через кавказские проходы [Балабанова, 2002, с. 85].

Позже Е.В. Перерва, рассмотревший патологическое состояние костяков из диагональных захоронений у мужчин, не выявил существенных различий в травматогенезе и 
в других патологиях по сравнению с суммарной среднесарматской и позднесарматской выборками. Вместе с тем даже анализ небольшой серии дал очень важную информацию. Например, для этой группы характерны высокие частоты заболеваний зубочелюстной системы: пародонтоза с прижизненной утратой зубов, эмалевой гипоплазии и др. По всем показателям физической изношенности суставов мужчины демонстрируют наибольшую активность. Свидетельством такой ситуации служат маркеры васкуляризации, последствия холодового стресса; маркеры механического стресса, связанного с верховой ездой и др. [Перерва, 2011, с. 202, 203].

С момента публикации этих статей краниологический материал пополнился, выборка увеличилась в два раза. Для рассмотрения краниологических особенностей «диагональников» изучалась серия, насчитывающая 66 черепов: 42 черепа получены из погребений среднесарматского времени (25 мужских и 17 женских) и 24 - позднесарматского, из них 14 деформированных черепов (8 мужских и 6 женских). К сожалению, большая часть диагональных погребений была ограблена еще в древности и краниологический материал из них часто отсутствует, а иногда плохой сохранности. При культурной атрибуции и хронологических определениях затруднение вызвало отсутствие четких культурных ориентиров. Такие погребения некоторые археологи относят к среднесарматской культуре, другие - к позднесарматской. Исследуемый в данной работе материал происходит из могильников Заволжья, Волго-Донского междуречья, Калмыкии, Астраханского правобережья, Нижнего Дона и Украины.

Мужские серии (25 среднесарматских и 6 позднесарматских черепов) без следов преднамеренной деформации характеризуются очень сходным морфотипом (табл. 1). У них мозговая коробка средней длины, широкая по пропорциям, мезобрахикранная у средних сарматов и брахикранная у поздних. Высота свода в среднесарматской группе средняя, а в позднесарматской - низкая. Основание черепа в обеих группах средней длины и широкое.

По строению лобной кости обе группы отличаются только по горизонтальной профи- лировке на месте изгиба: уплощенная в среднесарматской серии и резко профилированная в позднесарматской; вертикальный профиль наклонный с одинаковым значением угла от назион-метопион; сама кость почти широкая. Что касается длин лобной дуги и хорды, то они укладываются в среднемировые значения как по абсолютной длине, так и по индексу изгиба. У теменной кости хорды в обеих группах средней длины, но попадают в крайние варианты: дуга в среднесарматской группе средней длины, а в позднесарматской - короткая. Соответственно индекс изгиба темени в среднесарматской серии - средний, а в позднесарматской - большой. Затылочная кость широкая в обеих группах, с хордой и дугой средней длины, с малым индексом изгиба затылка у средних сарматов и средним у поздних.

Лицевой скелет широкий и средневысокий, с ослабленной горизонтальной профилировкой на обоих уровнях в среднесарматской серии и только на верхнем в позднесарматской. Отличаются группы и по вертикальному лицевому профилю: у средних сарматов он с тенденцией к мезогнатии, а в позднесарматской - ортогнатный. Нос и глазницы мезоморфного строения у средних сарматов. У поздних сарматов нос средневысокий и узкий, а глазницы среднеширокие и низкие. Переносье среднеширокое и высокое в обеих группах, а носовые кости узкие и высокие с большим углом выступания к линии профиля в среднесарматской группе и узкие средневысокие и умеренно выступающие в позднесарматской. Клыковая ямка умеренно углубленная в обеих группах (табл. 1).

Таким образом, из вышеприведенной усредненной характеристики хронологических групп «диагональников» видно сходство, которое можно интерпретировать, с одной стороны, как сохранение среднесарматских традиций определенной группой людей, с другой как и освоение культурных новаций. Сравнительный анализ по $t$-критерию Стьюдента дает только два признака с достоверно значимыми различиями: угол поперечного изгиба лба и длина теменной дуги (УПИЛ и 27).

Женский краниотип среднесарматской группы (16 черепов) из диагональных захоронений имеет несколько иное сочетание, чем 
синхронный мужской и позднесарматский женский (3 черепа) и характеризуется длинной, широкой по форме брахикранной мозговой капсулой, у которой свод низкий, а основание широкое и средней длины.

Лоб широкий, резко профилированный на уровне фронто-темпоральных точек. Лицевой скелет крупный, широкий и высокий, с резкой горизонтальной профилировкой и с тенденцией к мезогнатии в вертикальном профиле. Нос мезоморфный, глазница широкая и средневысокая. Носовые кости и переносье среднеширокие и высокие, угол носа к линии профиля большой.

Женская позднесарматская недеформированная серия, как и деформированные мужская и женская, резко отличается от среднесарматских серий и мужской недеформированной в сторону преобладания признаков, характеризующих тип длинноголовых европеоидов. Нарушает этот комплекс только угол профиля носа в обеих женских группах: он умеренный (табл. 2, 3).

Кроме этого, в деформированных группах присутствует весь комплекс признаков, который диагностирует их модифицированный тип. Это, прежде всего, уплощение лобной и затылочной костей с изменением их кривизны и выпуклости.

Как и в любой древней выборке, внутригрупповая изменчивость в исследуемой серии «диагональников» оказалась значительной. Анализ проводился методом главных компонент по набору признаков, исключающих признаки мозговой коробки, так как именно они в первую очередь испытывают на себе эффект деформации. Программа состоит из 17 признаков: ОРB; 45; 48; 55; 54; 51; 52; MC; MS; $\mathrm{SC}$; SS; FC; 77; <zm'; 72; 74; 75-1. В дальнейшем рассматривались значения первых трех главных компонент, на которые приходится более $50,0 \%$ от внутригрупповой изменчивости (табл. 4).

Первая главная компонента у мужчин является компонентой размера и разграничивает два крайних варианта. Первый - массивный с большим значением общеростовой величины, высоким лицом, которое резко профилировано в горизонтальной плоскости, высокими являются и нос, и глазница, и переносье, и носовые кости, которые к тому же еще и широкие. Второй тип - альтернативный первому - грацильный. Для него характерен следующий набор: малые значения общеростовой величины, низкое лицо с умеренной профилировкой на уровне глазниц, низкий нос, глазница, переносье и носовые кости. Переносье и носовые кости еще и узкие. В наибольшей степени первый краниотип просматривается на позднесарматских деформированных черепах из кургана 1 могильника Колобовка III, кургана 3 могильника Харьковка II, погребения 2 кургана 6 могильника Соленое Займище III и др. Второй краниотип в основном представлен среднесарматскими черепами из кургана 37 могильника Кузин хутор; кургана 9 могильника Балкин и др.

Вторая главная компонента при анализе внутригрупповой структуры мужской серии «диагональников» описывает имеющиеся различия по горизонтальной профилировке лица и углу выступания носа. На положительном полюсе будет локализоваться тип, у которого горизонтальный профиль лица ослаблен, а нос умеренно выступающий; на отрицательном, наоборот, тип с резкой горизонтальной профилировкой, у которого нос к линии профиля резко выступающий. Таким образом, II ГК разграничивает черепа со смешанными европеоидно-монголоидными чертами от европеоидов. Смешанный европеоидно-монголоидный комплекс встречается на позднесарматских деформированных черепах из кургана 5 могильника Аксай II, среднесарматских черепах из кургана 14 могильника Новая Филипповка, кургана 3 могильника Колобовка III, кургана 37 могильника Восточный Маныч II и др. С резкими европеоидными особенностями оказались деформированные черепа из кургана 3 могильника Харьковка II, кургана 4 могильника Абганерово IV, среднесарматские из кургана 37 могильника Кузин, кургана 3 могильника Малая Воробцовка и др.

Третья главная компонента описывает изменчивость по вертикальному профилю и выделяет, с одной стороны, черепа, у которых мелкая клыковая ямка с ортогнатным лицом, с другой - черепа с глубокой клыковой ямкой, у которых тенденция к общему и альвеолярному прогнатизму. Максимальные положительные значения по этой главной компоненте имеют позднесарматские деформирован- 
ные черепа из кургана 5 могильника Аксай II, кургана 4 могильника Абганерово IV, среднесарматские черепа из погребения 3 кургана 7 могильника Маляевка III, кургана 37 могильника Восточный Маныч II и др.

Таким образом, в мужской группе доминируют массивные черепа с резкой горизонтальной профилировкой лица на верхнем уровне и грацильные с уплощением на уровне глазниц. Кроме этого, имеются черепа, у которых горизонтальная профилировка лица ослаблена на обоих уровнях в сочетании с умеренным углом выступания носа. В данном случае следует подозревать монголоидную примесь.

Морфологическое разнообразие мужской части «диагональников» демонстрирует и дендрограмма кластеризации, и четырехпольный график неметрического многомерного шкалирования (рис. 5).

Аналогичный анализ женской группы тоже показал внутригрупповую гетерогенность (табл. 4). Первая главная компонента является переменной, разграничивающей расовые типы. На положительный полюс выходит краниотип, сочетающий узкое высокое клиногнатное лицо с широкими и высокими носовыми костями, а на отрицательный - тип с широким низким слабо профилированным лицом и носовыми костями. Высокое лицо с резкими европеоидными качествами встречается на среднесарматском черепе из кургана 10 могильника Авиловский II и позднесарматском из кургана 55 могильника Старица, на деформированном черепе из кургана 34 могильника Перегрузное I и др. Смешанный европеоидно-монголоидный комплекс диагностируется на черепах из среднесарматского погребения 3 кургана 10 могильника Перегрузное I и погребения 2 кургана 21 могильника Сладковка, на деформированных черепах из курганов 8 и 42 могильника Кривая Лука XVII и др. На этих черепах углы вертикальной профилировки варьируются в пределах 141-150 назомалярный угол (77) и 130-136 - зигомаксилярный угол (<zm'). Как показывает исследование, и угол выступания носовых костей на таких черепах либо умеренно выступающий, либо слабо выступающий.

Вторая переменная при анализе женских черепов отражает изменчивость высотных признаков лицевого скелета и угол его верти- кального профиля. Максимальные значения будут иметь черепа, сочетающие высокое лицо, нос и глазницу с ортогнатной профилировкой, а минимальные - низкое лицо, нос и глазницу с общей тенденцией к прогнатизму. Группа черепов с первым комплексом почти повторяет группу, которая по I ГК была определена как европеоидно-монголоидные метисы. Второй комплекс встречается на двух среднесарматских черепах из курганов 10 и 11 могильника Авиловский II, и на одном позднесарматском из погребения кургана 8 могильника Племхоз кургане.

Третья главная компонента имеет высокие нагрузки только с двумя признаками: ширина переносья и угол выступания носа. На основе распределения изменчивости по этой компоненте выявляется то, что положительные максимальные значения имеют черепа, на которых узкое переносье и резко выступающий нос, а отрицательные - широкое переносье и умеренно выступающий нос. По второму комплексу снова выделились те же черепа с монголоидной примесью, что и прежде, это черепа из погребений курганов 8 и 42 могильника Кривая Лука XVII, кургана 4 могильника Новый Рогачик и др. (рис. 6).

Итак, на основе результатов внутригруппового анализа женской группы в первую очередь выделяются два крайних варианта: европеоидный и смешанный европеоидно-монголоидный. Такую картину демонстрируют и результаты многомерного неметрического шкалирования, и кластерный анализ (рис. 5, 6).

При распределении материала по локальным группам на основе картографирования памятников выясняется, что для таких групп характерно краниологическое разнообразие. Наиболее европеоидной оказалась доно-аксайская мужская группа. Для нее характерен тип низколицых длинноголовых европеоидов. Мужская серия из Заволжья оказалась длинноголовой, высокосводчатой, но с ослабленной горизонтальной профилировкой лица. Очень похожий набор признаков, но с несколько более короткой и широкой черепной коробкой имеет серия из могильников Калмыкии. Группы из астраханского правобережья и украинская - брахикранные с ослабленной профилировкой горизонтальных лицевых структур. Таким образом, длинноголовый вариант, вы- 
деленный I ГК, имеет весомую долю в доноаксайской и заволжских группах, а брахикранный - в астраханской и калмыцкой группах. Женские локальные выборки, в отличие от мужских, характеризуются более отчетливо выраженными европеоидными чертами. Горизонтальная профилировка во всех трех группах резкая. Лишь в донской серии несколько нарушена профилировка лица на уровне назомалярных точек.

\section{Основные выводы}

Все вышесказанное было бы очень важно при условии массовости материала. Поэтому приходится констатировать только результаты анализа внутригрупповых зависимостей «диагональников», который показывает отсутствие в этой группе единого краниологического комплекса. При этом четко выделяется тип длинноголовых европеоидов, который преобладает в первых веках нашей эры на сарматской территории, и брахикранный европеоидный тип с ослабленной горизонтальной профилировкой лицевых структур, характерный для раннесарматского краниокомплекса. Кроме этого, четко выделенный смешанный европеоидно-монголоидный вариант как среди «диагональников», так и по всей среднесарматской выборке позволяет уверенно говорить о восточных (южносибирских) миграциях, которые могли являться источником культурных новаций и новых антропологических компонентов (рис. 7, 8).

Анализ диагональных погребений первых веков демонстрирует крайне интересные процессы взаимодействия различных по своему происхождению групп кочевого населения. Вопервых, присутствие брахикранного компонента в краниотипе «диагональников» может указывать на использование этого обряда населением, связанным с раннесарматской культурой, участвовавшим в формировании сред- несарматской культуры. Однако этот обряд не фиксируется в раннесарматских памятниках последних веков до нашей эры. Соответственно, можно предположить, что идея диагонального обряда возрождается в сарматском мире с приходом носителей среднесарматской культуры. Но наибольшую популярность получает в определенной части общества, автохтонного по отношению к мигрантам I в. н.э. Однако нельзя исключать и миграционный характер брахикранного компонента, тем более что в этой группе диагональников отмечается большая уплощенность горизонтальной профилировки лицевого скелета на обоих уровнях, что отмечается в восточной группе кочевников более раннего времени.

В процессе формирования позднесарматской культуры второй половины II - начала III в. н.э. на археологическом материале наблюдается общая тенденция к вытеснению среднесарматских культурных компонентов, и диагонального обряда в том числе, позднесарматскими традициями. Однако антропологический материал показывает более сложную картину взаимодействия. Часть пришлого позднесарматского населения воспринимает традицию диагональных захоронений, возможно, через брачные контакты. Не исключено, что существование во второй половине II - первой половине III в. мощной группировки среднесарматского населения в Нижнем Поволжье и в первую очередь в Волго-Донском междуречье позволяло ей достаточно долго, вплоть до начала III в., противостоять доминированию позднесарматских традиций и даже включать в свой состав представителей миграционного населения. Возможно, что и традиции субстратного населения могли восприниматься пришлым позднесарматским населением, что нашло отражение в длительном существовании в Волго-Донском междуречье таких среднесарматских традиций, как южная ориентировка. 


\section{ИЛЛЮСТРАЦИИ}

Таблииа 1

Средние значения и указатели мужских краниологических серий из диагональных комплексов. Серии без следов искусственной деформации

\begin{tabular}{|c|c|c|c|c|c|c|c|c|c|c|}
\hline \multirow{2}{*}{$\begin{array}{c}\text { № по } \\
\text { Мартину и др. }\end{array}$} & \multicolumn{5}{|c|}{ I - первая половина II в. н.э. } & \multicolumn{5}{|c|}{$\begin{array}{c}\text { Вторая половина II - } \\
\text { первая половина III в. н.э. }\end{array}$} \\
\hline & $n$ & $X$ & $s$ & $\min$ & $\max$ & $n$ & $X$ & $s$ & $\min$ & $\max$ \\
\hline 1 & 22 & 184,7 & 7,0 & 173 & 200 & 6 & 182,2 & 6 & 176 & 192 \\
\hline 8 & 22 & 145,5 & 6,6 & 132 & 163 & 5 & 147,6 & 4,9 & 144 & 156 \\
\hline $8: 1$ & 20 & 79,2 & 5,2 & 70,1 & 90,0 & 5 & 82 & 3,5 & 78,0 & 86,7 \\
\hline 17 & 14 & 134,5 & 7,1 & 124 & 146 & 4 & 131 & 4,1 & 128 & 137 \\
\hline $17: 1$ & 14 & 73,3 & 4,7 & 63,0 & 82,7 & 4 & 72,7 & 0,9 & 71,4 & 73,7 \\
\hline $17: 8$ & 14 & 92,9 & 7,4 & 76,1 & 102,2 & 4 & 90,1 & 3,2 & 87,2 & 94,5 \\
\hline OPB & 14 & 270,4 & 6,6 & 259,0 & 283,8 & 4 & 266,1 & 4,8 & 261,5 & 280,1 \\
\hline M2 & 20 & 267,5 & 14,2 & 238,9 & 295,0 & 5 & 265,8 & 9,5 & 255,2 & 280,1 \\
\hline M3 & 14 & 1795,1 & 132,2 & 1553,0 & 2108,2 & 4 & 1718,4 & 91,2 & 1633,3 & 1847,4 \\
\hline 5 & 13 & 100,3 & 6,4 & 88 & 110 & 4 & 100 & 3,2 & 97 & 104 \\
\hline 20 & 17 & 116,0 & 4,6 & 109 & 125 & 4 & 112,5 & 3,1 & 110 & 117 \\
\hline 9 & 24 & 98,4 & 4,6 & 91 & 111 & 6 & 98,2 & 5,6 & 91 & 107 \\
\hline УПИЛ & 20 & 140,0 & 4,4 & 133,1 & 149,4 & 6 & 135,5 & 3,3 & 129,8 & 138,6 \\
\hline 11 & 19 & 131,2 & 8,7 & 121 & 155 & 4 & 133,8 & 2,1 & 132 & 136 \\
\hline 45 & 19 & 136,5 & 4,4 & 125 & 145 & 5 & 137,6 & 6 & 130 & 145 \\
\hline $45: 8$ & 17 & 94,4 & 3,3 & 88,0 & 100,8 & 5 & 93,3 & 4,7 & 89,7 & 100 \\
\hline 40 & 12 & 94,3 & 9,3 & 76,0 & 112 & 4 & 94,8 & 3,4 & 92 & 99 \\
\hline $40: 5$ & 12 & 94,2 & 6,1 & 81 & 102,1 & 4 & 94,7 & 0,6 & 93,9 & 95,2 \\
\hline 48 & 21 & 70,5 & 4,6 & 60 & 79 & 5 & 68,8 & 6,0 & 60 & 76 \\
\hline $48: 17$ & 12 & 51,2 & 2,8 & 46,2 & 56,2 & 4 & 51,1 & 3,7 & 46,2 & 54,7 \\
\hline $48: 45$ & 17 & 51,6 & 4,4 & 46,2 & 63,2 & 5 & 49,9 & 3,6 & 46,1 & 54,3 \\
\hline 43 & 23 & 108 & 3,9 & 101 & 115 & 6 & 107,2 & 5,2 & 101 & 115 \\
\hline 46 & 20 & 96,05 & 4,4 & 88 & 103 & 5 & 93 & 4,6 & 89 & 98 \\
\hline 54 & 20 & 25,0 & 1,6 & 22 & 28 & 6 & 24,25 & 0,9 & 23,5 & 26 \\
\hline 55 & 20 & 51,8 & 2,8 & 46 & 57 & 5 & 51,4 & 2,1 & 49 & 54 \\
\hline $54: 55$ & 19 & 48,6 & 4,0 & 39,3 & 56,0 & 5 & 46,3 & 2,1 & 43,4 & 49 \\
\hline 51 & 20 & 42,7 & 1,9 & 39 & 47 & 6 & 42,8 & 3,9 & 39 & 48 \\
\hline 52 & 20 & 33,1 & 2,1 & 29 & 37 & 5 & 32,6 & 0,65 & 32 & 33,5 \\
\hline $52: 51$ & 20 & 77,7 & 5,8 & 68,1 & 88,1 & 5 & 76,1 & 7,8 & 67,7 & 84,6 \\
\hline $\mathrm{DC}$ & 15 & 21,3 & 2,3 & 17,5 & 25,0 & 4 & 21,5 & 1,8 & 19,5 & 23,7 \\
\hline DS & 15 & 13,7 & 2,0 & 8,5 & 17,0 & 4 & 14,1 & 1 & 13,0 & 15,4 \\
\hline DS:DC & 15 & 64,9 & 11,25 & 37,0 & 79,2 & 4 & 66 & 8,1 & 58,6 & 74,0 \\
\hline $\mathrm{SC}$ & 19 & 8,6 & 2,4 & 5,0 & 12,0 & 4 & 7,25 & 1,6 & 5,3 & 9,2 \\
\hline SS & 19 & 5,1 & 1,1 & 2,5 & 7,0 & 4 & 4,05 & 0,4 & 3,5 & 4,5 \\
\hline SS:SC & 19 & 60,5 & 12,0 & 48,2 & 92,3 & 4 & 58,6 & 17,1 & 38,0 & 79,2 \\
\hline $\mathrm{FC}$ & 18 & 5,4 & 1,4 & 3 & 9 & 4 & 4,9 & 0,3 & 4,5 & 5,2 \\
\hline 77 & 23 & 142,9 & 4,4 & 133,1 & 150,5 & 6 & 140,6 & 1,7 & 138,6 & 143,3 \\
\hline$<\mathrm{zm}^{\prime}$ & 20 & 130,7 & 5,5 & 121,5 & 139,7 & 6 & 129,65 & 6,3 & 123,3 & 140,1 \\
\hline 32 & 15 & 81,5 & 6,3 & 69 & 90 & 4 & 81,8 & 6,65 & 75 & 90 \\
\hline 72 & 14 & 85,0 & 4,9 & 71 & 91 & 4 & 87,2 & 1,9 & 86 & 90 \\
\hline 74 & 14 & 76,1 & 7,5 & 61 & 93 & 4 & 75 & 6,1 & 67 & 81 \\
\hline $75-1$ & 16 & 31,25 & 7,0 & 19 & 44 & 4 & 27,8 & 6,4 & 20 & 33 \\
\hline
\end{tabular}


Средние значения и указатели женских краниологических серий из диагональных комплексов. Серии без следов искусственной деформации

\begin{tabular}{|c|c|c|c|c|c|c|c|c|c|c|}
\hline \multirow{2}{*}{$\begin{array}{c}\text { № по } \\
\text { Мартину и др. }\end{array}$} & \multicolumn{5}{|c|}{ I - первая половина II в. н.э. } & \multicolumn{5}{|c|}{$\begin{array}{c}\text { Вторая половина II - } \\
\text { первая половина III в. н.э. }\end{array}$} \\
\hline & $n$ & $X$ & $S$ & $\min$ & $\max$ & $n$ & $X$ & $S$ & $\min$ & $\max$ \\
\hline 1 & 14 & 177,1 & 10,1 & 160 & 192 & 3 & 184,3 & 8,0 & 176 & 192 \\
\hline 8 & 14 & 141,7 & 8,05 & 125 & 151 & 3 & 135,0 & 7,8 & 126 & 140 \\
\hline $8: 1$ & 14 & 80,3 & 8,1 & 65,3 & 91,9 & 3 & 73,3 & 7,3 & 65,3 & 79,5 \\
\hline 17 & 9 & 124,0 & 4,7 & 117 & 131 & 1 & 131 & & & \\
\hline $17: 1$ & 9 & 70,7 & 4,3 & 66,1 & 79,5 & 1 & 74,4 & & & \\
\hline $17: 8$ & 9 & 88,2 & 6,9 & 79,05 & 101,6 & 1 & 93,6 & & & \\
\hline OPB & 9 & 257,5 & 4,3 & 249,7 & 261,2 & 1 & 260,3 & & & \\
\hline M2 & 14 & 250,6 & 13,5 & 235,2 & 283,9 & 3 & 248,5 & 7,9 & 241,9 & 257,2 \\
\hline M3 & 9 & 1534,3 & 63,2 & 1425,6 & 1613,9 & 1 & 1613,9 & & & \\
\hline 5 & 8 & 95,6 & 7,9 & 82 & 108 & 1 & 95 & & & \\
\hline 20 & 12 & 110,5 & 4,2 & 106 & 118 & 3 & 111,3 & 5,9 & 107 & 118 \\
\hline 9 & 16 & 96,1 & 4, & 91 & 108 & 3 & 93,3 & 2,3 & 92 & 96 \\
\hline УПИЛ & 10 & 136,6 & 3,6 & 131,0 & 141,4 & 3 & 133,7 & 3,8 & 131 & 136,4 \\
\hline 11 & 10 & 124,8 & 9,9 & 102 & 138 & 3 & 115,0 & 11,4 & 102 & 123 \\
\hline 45 & 11 & 129,9 & 7,6 & 114 & 142 & 3 & 120,8 & 6,3 & 114 & 126,5 \\
\hline $45: 8$ & 11 & 91,8 & 5,1 & 84,4 & 103,2 & 3 & 89,5 & 1,5 & 87,8 & 90,5 \\
\hline 40 & 7 & 97,9 & 5,6 & 89 & 105 & 1 & 100 & & & \\
\hline $40: 5$ & 7 & 102,2 & 4,8 & 95,8 & 108,5 & 1 & 105,3 & & & \\
\hline 48 & 14 & 69,4 & 4,2 & 62,5 & 76,0 & 3 & 68,3 & 6,8 & 63 & 76 \\
\hline $48: 17$ & 8 & 54,5 & 4,1 & 48,1 & 60,0 & 1 & 48,1 & & & \\
\hline $48: 45$ & 10 & 53,5 & 5,7 & 45,8 & 66,7 & 3 & 56,7 & 8,4 & 49,8 & 66,1 \\
\hline 43 & 15 & 104,7 & 4,5 & 95 & 110 & 3 & 100,7 & 2,3 & 98 & 102 \\
\hline 46 & 11 & 93,0 & 4,4 & 86 & 98 & 2 & 91 & & 86 & 96 \\
\hline 54 & 15 & 24,1 & 1,3 & 22 & 26 & 3 & 23,2 & 0,3 & 23 & 23,5 \\
\hline 55 & 15 & 50,5 & 3,0 & 45 & 56 & 3 & 50,3 & 5,5 & 45 & 56 \\
\hline $54: 55$ & 14 & 47,9 & 3,6 & 41,1 & 54,2 & 3 & 46,4 & 5,6 & 41,1 & 42,2 \\
\hline 51 & 15 & 41,9 & 2,3 & 38 & 45 & 3 & 40,5 & 0,9 & 40 & 41,5 \\
\hline 52 & 15 & 34,5 & 2,7 & 31 & 40 & 3 & 34,7 & 3,8 & 32 & 39 \\
\hline $52: 51$ & 15 & 82,4 & 6,5 & 74,4 & 74,4 & 3 & 97,5 & 11,6 & 74,7 & 97,5 \\
\hline $\mathrm{DC}$ & 10 & 19,9 & 2,8 & 14,8 & 24 & 1 & 21 & & & \\
\hline DS & 9 & 12,3 & 1,8 & 9,5 & 15 & 1 & 10 & & & \\
\hline DS:DC & 9 & 64,1 & 14,9 & 47 & 92,9 & 1 & 47,6 & & & \\
\hline $\mathrm{SC}$ & 14 & 8,8 & 2,0 & 5 & 11,2 & 2 & 10,05 & & 9,1 & 11 \\
\hline SS & 12 & 4,7 & 0,7 & 3,7 & 6,5 & 2 & 4,2 & & 4,2 & 4,2 \\
\hline SS:SC & 12 & 54,4 & 11,8 & 41,0 & 74,0 & 2 & 42,2 & & 38,2 & 46,2 \\
\hline $\mathrm{FC}$ & 12 & 4,25 & 1,5 & 1,5 & 7 & 3 & 4,5 & 0,9 & 3,8 & 5,5 \\
\hline 77 & 15 & 139,6 & 5,9 & 131,0 & 150 & 3 & 135,3 & 4,5 & 131,3 & 140,2 \\
\hline$<\mathrm{zm}$ ' & 11 & 127,3 & 5,1 & 119,7 & 136,2 & 3 & 124,9 & 3,0 & 122 & 128 \\
\hline 32 & 10 & 82,4 & 4,0 & 78 & 90 & 3 & 82 & 2,6 & 80 & 85 \\
\hline 72 & 10 & 84,0 & 3,7 & 79 & 91 & 3 & 84 & 4,6 & 79 & 88 \\
\hline 74 & 10 & 75,1 & 6,6 & 67 & 88 & 3 & 74,0 & 7,2 & 68 & 82 \\
\hline $75-1$ & 9 & 26,9 & 7,0 & 18 & 39 & 2 & 21,0 & & 18 & 24 \\
\hline
\end{tabular}


М.А. Балабанова, М.В. Кривошеев. Диагональные погребения как маркер преемственности в сарматских культурах

Таблица 3

\section{Средние значения и указатели краниологических серий}

из диагональных комплексов второй половины II - IV в. н.э.

Серии со следами искусственной деформации

\begin{tabular}{|c|c|c|c|c|c|c|c|c|c|c|}
\hline \multirow{2}{*}{$\begin{array}{c}\text { № по } \\
\text { Мартину и др. }\end{array}$} & \multicolumn{5}{|c|}{ Мужчины } & \multicolumn{5}{|c|}{ Женщины } \\
\hline & $n$ & $X$ & $s$ & $\min$ & $\max$ & $n$ & $X$ & $s$ & $\min$ & $\max$ \\
\hline 1 & 8 & 187,1 & 9,4 & 176 & 202 & 6 & 176,0 & 3,9 & 171 & 181 \\
\hline 8 & 7 & 133,7 & 8,4 & 123 & 147 & 7 & 135,7 & 5,8 & 128 & 142 \\
\hline $8: 1$ & 7 & 71,9 & 5,4 & 65,3 & 79 & 6 & 76,6 & 3,9 & 72,1 & 82,1 \\
\hline 17 & 5 & 138,4 & 4,7 & 134 & 146 & 4 & 138,0 & 10,5 & 128 & 152 \\
\hline $17: 1$ & 5 & 75,1 & 2,7 & 72,2 & 78,4 & 4 & 78,4 & 5,0 & 73,6 & 85,4 \\
\hline $17: 8$ & 5 & 103,6 & 8,6 & 91,8 & 112,2 & 4 & 101,1 & 10,0 & 92,1 & 110,9 \\
\hline OPB & 5 & 267,1 & 11,5 & 255,2 & 272 & 4 & 262,3 & 6,2 & 256,9 & 271,2 \\
\hline M2 & 7 & 249,2 & 21,2 & 216,5 & 273,4 & 6 & 237,0 & 10,2 & 218,9 & 245,7 \\
\hline M3 & 5 & 1717,6 & 206,0 & 1493,7 & 1946,5 & 4 & 1659,8 & 133,3 & 1547,9 & 1853,3 \\
\hline 5 & 5 & 106,2 & 8,6 & 94 & 118 & 4 & 102,5 & 2,6 & 99 & 105 \\
\hline 20 & 5 & 116,2 & 5,6 & 111 & 124 & 7 & 120,3 & 8,6 & 110 & 133 \\
\hline 9 & 8 & 98,6 & 5,6 & 91 & 109 & 7 & 96,9 & 4,1 & 91 & 102 \\
\hline УПИЛ & 6 & 135,1 & 5,8 & 124,9 & 140,4 & 5 & 132,8 & 2,5 & 130,8 & 137 \\
\hline 11 & 6 & 126,5 & 5,8 & 121 & 137 & 7 & 123,3 & 4,1 & 117 & 130 \\
\hline 45 & 6 & 137,7 & 5,3 & 129 & 143 & 7 & 128,1 & 5,5 & 130 & 134 \\
\hline $45: 8$ & 6 & 98,0 & 5,2 & 91,8 & 103,5 & 7 & 94,5 & 4,8 & 90,8 & 104,7 \\
\hline 40 & 4 & 103,5 & 5,5 & 98 & 110 & 4 & 98,0 & 2,9 & 95 & 101 \\
\hline $40: 5$ & 4 & 94,8 & 2,9 & 91,6 & 98,1 & 4 & 95,6 & 1,7 & 93,1 & 97,0 \\
\hline 48 & 6 & 75,3 & 5,3 & 67 & 80 & 7 & 70,3 & 3,0 & 66 & 75 \\
\hline $48: 17$ & 4 & 53,5 & 3,6 & 49,6 & 58,0 & 4 & 51,4 & 3,8 & 46,0 & 54,5 \\
\hline $48: 45$ & 6 & 54,8 & 4,5 & 47,2 & 59,7 & 7 & 54,3 & 4,5 & 49,3 & 62,5 \\
\hline 43 & 7 & 108,6 & 5,6 & 100 & 115 & 6 & 105,8 & 3,5 & 102 & 109 \\
\hline 46 & 6 & 101 & 4,4 & 97 & 109 & 7 & 96,3 & 2,8 & 94 & 102 \\
\hline 54 & 5 & 26,4 & 1,5 & 24 & 28 & 7 & 24,4 & 1,7 & 23 & 25,5 \\
\hline 55 & 6 & 53,7 & 3,2 & 51 & 58 & 7 & 50,8 & 1,8 & 48 & 54 \\
\hline $54: 55$ & 5 & 48,8 & 2,4 & 46,6 & 51,8 & 7 & 48,1 & 1,7 & 46 & 50 \\
\hline 51 & 6 & 43,4 & 1,9 & 41 & 46 & 7 & 41,9 & 1,2 & 40 & 43 \\
\hline 52 & 6 & 34,3 & 2,2 & 31 & 37 & 7 & 35,3 & 1,8 & 33 & 38 \\
\hline $52: 51$ & 6 & 79,0 & 4,8 & 75 & 87 & 7 & 84,4 & 4,8 & 79,1 & 92,7 \\
\hline $\mathrm{DC}$ & 5 & 21,6 & 1,0 & 20 & 22,7 & 7 & 24,9 & 3,4 & 20,7 & 29,6 \\
\hline DS & 5 & 14,0 & 2,0 & 11,7 & 15,5 & 7 & 12,6 & 1,5 & 10,8 & 15,0 \\
\hline DS:DC & 5 & 65,0 & 10,3 & 54,2 & 77,5 & 7 & 52,4 & 10,3 & 39,9 & 72,5 \\
\hline $\mathrm{SC}$ & 7 & 8,9 & 2,1 & 4,5 & 10,8 & 7 & 9,3 & 1,8 & 5,8 & 11,6 \\
\hline SS & 7 & 5,9 & 1,8 & 2,3 & 7,7 & 7 & 3,9 & 1,3 & 2,2 & 5,9 \\
\hline SS:SC & 7 & 65,0 & 8,4 & 51,1 & 72,0 & 7 & 42,1 & 9,1 & 30,3 & 52,9 \\
\hline $\mathrm{FC}$ & 5 & 4,7 & 0,7 & 3,5 & 5,2 & 6 & 3,6 & 0,8 & 2 & 4,1 \\
\hline 77 & 8 & 138,1 & 7,5 & 127,8 & 151,9 & 7 & 138,4 & 4,2 & 133,5 & 143,1 \\
\hline$<\mathrm{zm}^{\prime}$ & 6 & 127,5 & 4,6 & 124,5 & 136,4 & 7 & 128,7 & 4,6 & 123 & 136,6 \\
\hline 32 & 6 & 73,7 & 4,7 & 66 & 79 & 7 & 78,7 & 3,8 & 72 & 83 \\
\hline 72 & 6 & 89,7 & 3,3 & 85 & 94 & 7 & 87,1 & 3,1 & 82 & 91 \\
\hline 74 & 5 & 80,8 & 10,6 & 66 & 91 & 7 & 76,6 & 6,8 & 64 & 86 \\
\hline $75-1$ & 6 & 30,5 & 7,7 & 20 & 41 & 7 & 22,6 & 4,5 & 17 & 29 \\
\hline
\end{tabular}


Элементы первых трех главных компонент при анализе внутригрупповой структуры «диагональников»

\begin{tabular}{|c|c|c|c|c|c|c|}
\hline \multirow{2}{*}{$\begin{array}{c}\text { № по } \\
\text { Мартину и др. }\end{array}$} & \multicolumn{3}{|c|}{ Мужчины } & \multicolumn{3}{|c|}{ Женщины } \\
\hline & $\mathrm{I}$ & II & III & $\mathrm{I}$ & II & III \\
\hline OPB & 0,601 & 0,537 & $-0,194$ & $-0,209$ & 0,308 & $-0,351$ \\
\hline 45 & 0,493 & $-0,002$ & $-0,243$ & $-0,580$ & $-0,189$ & 0,105 \\
\hline 48 & 0,646 & 0,010 & 0,273 & 0,524 & 0,574 & 0,230 \\
\hline 55 & 0,633 & 0,111 & 0,206 & 0,416 & 0,810 & 0,280 \\
\hline 54 & 0,380 & 0,321 & $-0,021$ & 0,430 & 0,311 & 0,109 \\
\hline 51 & 0,448 & 0,037 & 0,203 & $-0,463$ & 0,433 & 0,355 \\
\hline 52 & 0,569 & 0,308 & 0,078 & 0,176 & 0,741 & $-0,115$ \\
\hline $\mathrm{MC}$ & 0,503 & 0,585 & $-0,239$ & 0,257 & $-0,007$ & $-0,668$ \\
\hline MS & $\mathbf{0 , 5 4 5}$ & $-0,176$ & $-0,302$ & 0,404 & $-0,457$ & 0,403 \\
\hline $\mathrm{SC}$ & 0,712 & $-0,158$ & $-0,333$ & 0,770 & $-0,237$ & $-0,381$ \\
\hline SS & 0,744 & $-0,492$ & $-0,121$ & 0,691 & $-0,385$ & 0,419 \\
\hline FC & $-0,045$ & 0,408 & $-0,568$ & 0,414 & $-0,007$ & $-0,170$ \\
\hline 77 & $-0,549$ & 0,569 & $-0,268$ & $-0,784$ & $-0,082$ & 0,113 \\
\hline$<\mathrm{zm}^{\prime}$ & $-0,089$ & 0,681 & 0,264 & $-0,655$ & 0,423 & 0,139 \\
\hline 72 & 0,186 & $-0,090$ & 0,750 & $-0,059$ & 0,659 & $-0,467$ \\
\hline 74 & 0,200 & 0,281 & $\mathbf{0 , 7 3 0}$ & 0,218 & 0,238 & $-0,203$ \\
\hline $75-1$ & 0,134 & $-0,596$ & $-0,158$ & 0,263 & 0,348 & 0,638 \\
\hline Собственные числа & 4,108 & 2,536 & 2,120 & 3,892 & 3,160 & 2,074 \\
\hline \% дисперсии & 24,162 & 14,919 & 12,470 & 22,897 & 18,589 & 12,199 \\
\hline
\end{tabular}




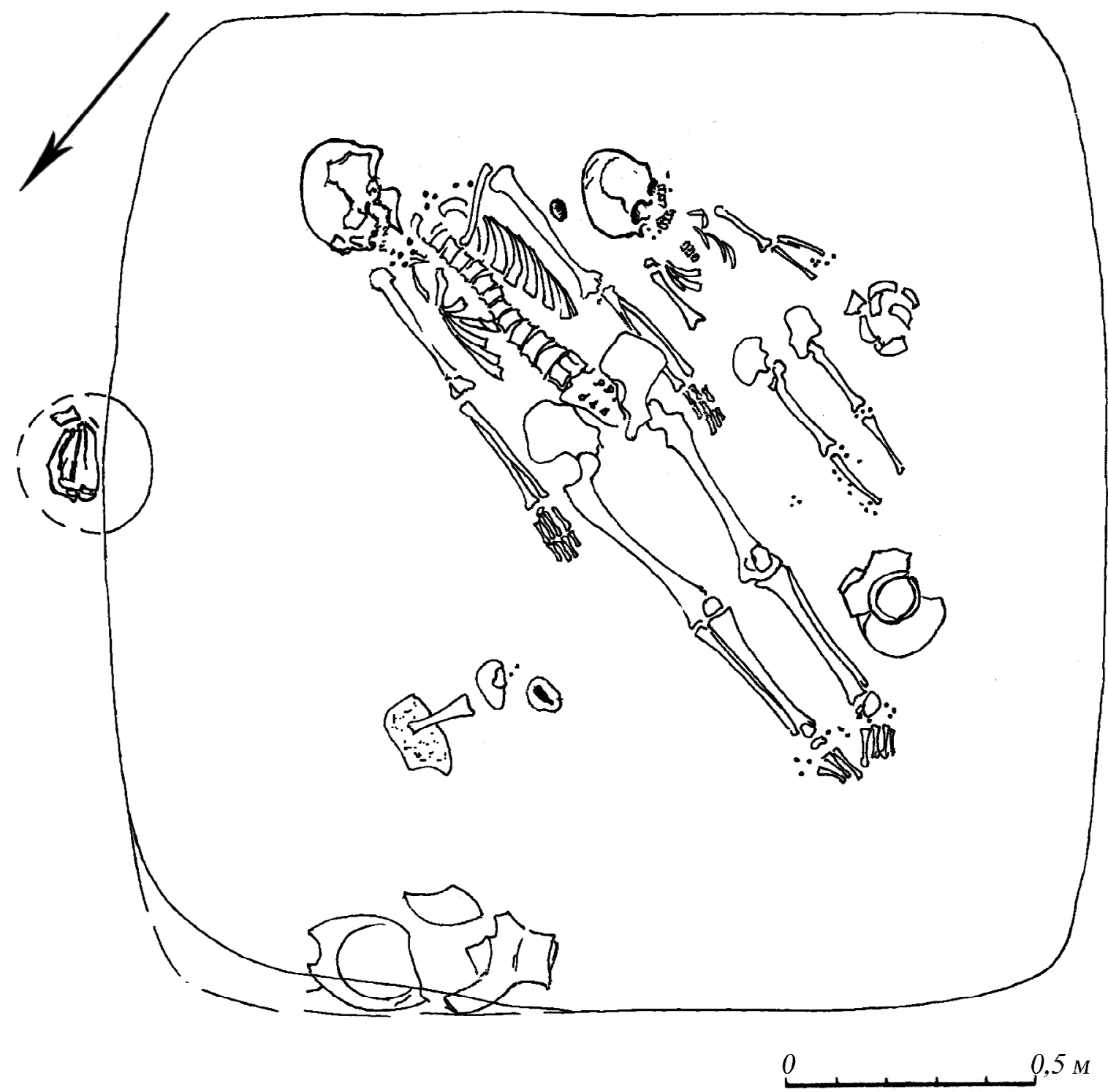

Рис. 1. Диагональное погребение среднесарматского времени (Перегрузное I, кург. 38)

Fig. 1. Diagonal burial of the Middle Sarmatian time (Peregruznoe I, barrow 38) 
M.A. Balabanova, M.V. Krivosheev. Diagonal Burials as a Marker of Succession of Sarmatian Cultures

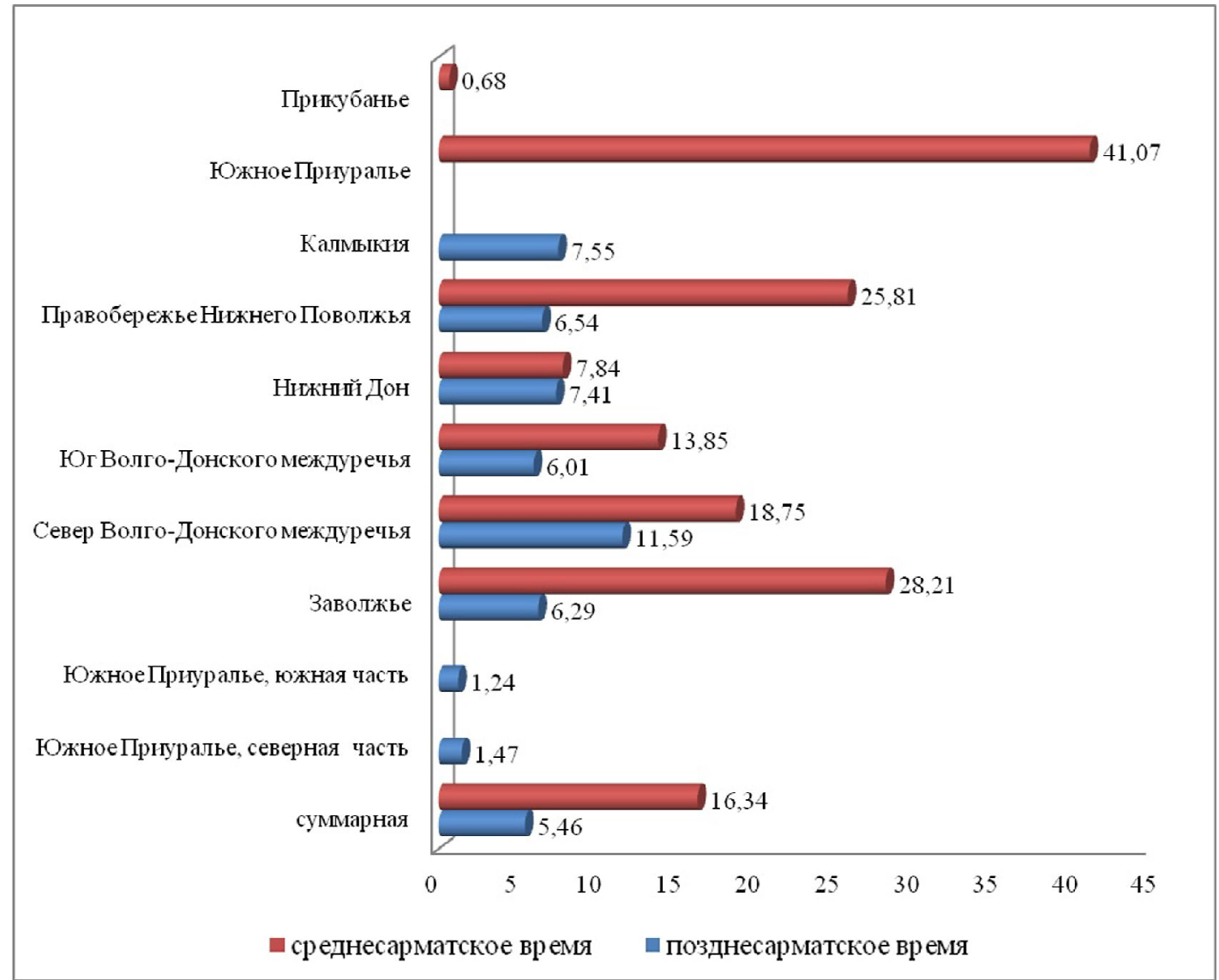

Рис. 2. Распределение диагональных захоронений среднесарматского и позднесарматского времени по территориальным группам (по: [Сергацков, 2002, с. 90, табл. 12; Мошкова, 2009, с. 88, табл. 15])

Fig. 2. Distribution of diagonal burials of the Middle Sarmatian and Late Sarmatian times by territorial groups (according to Sergatskov, 2002, p. 90, Table 12; Moshkova, 2009, p. 88, Table 15) 


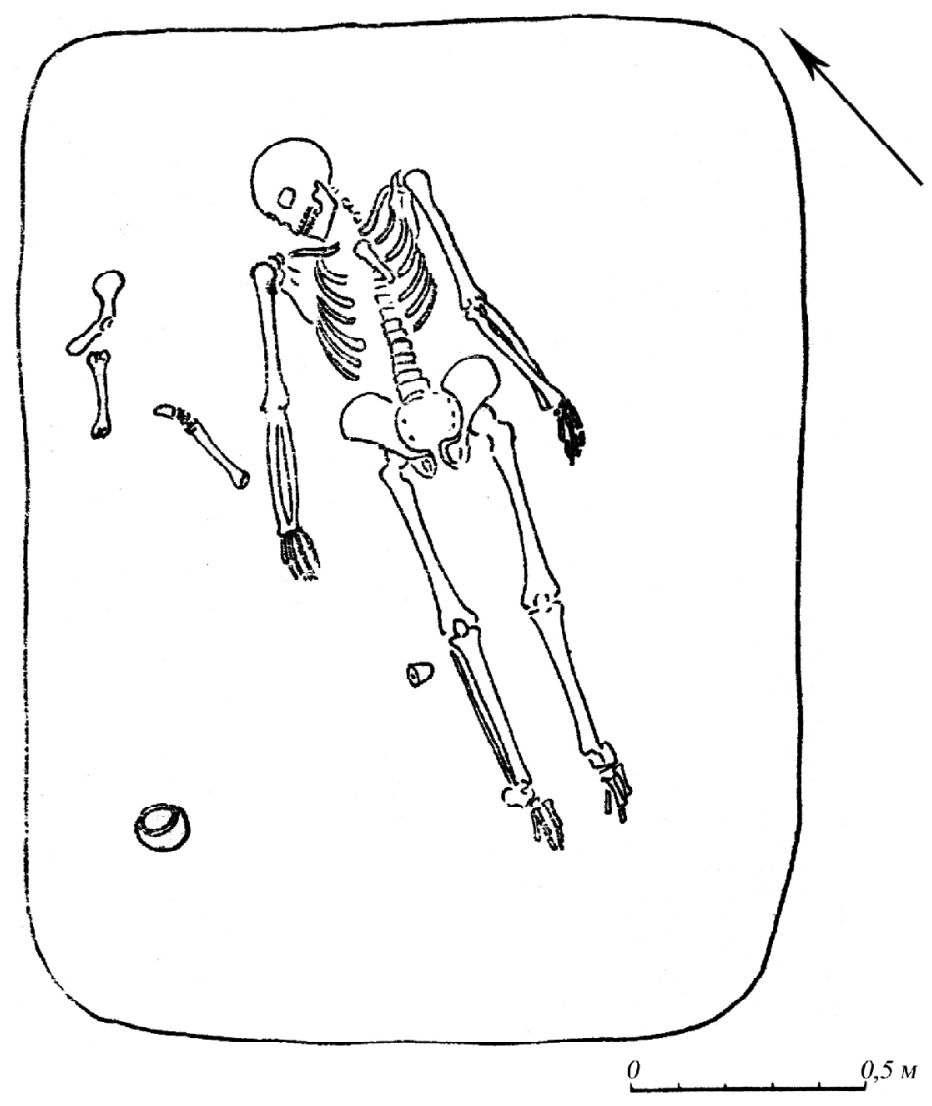

Рис. 3. Диагональное погребение позднесарматского времени (Максютово II, кург. 2)

Fig. 3. Diagonal burial of the Late Sarmatian time (Maksyutovo II, barrow 2)

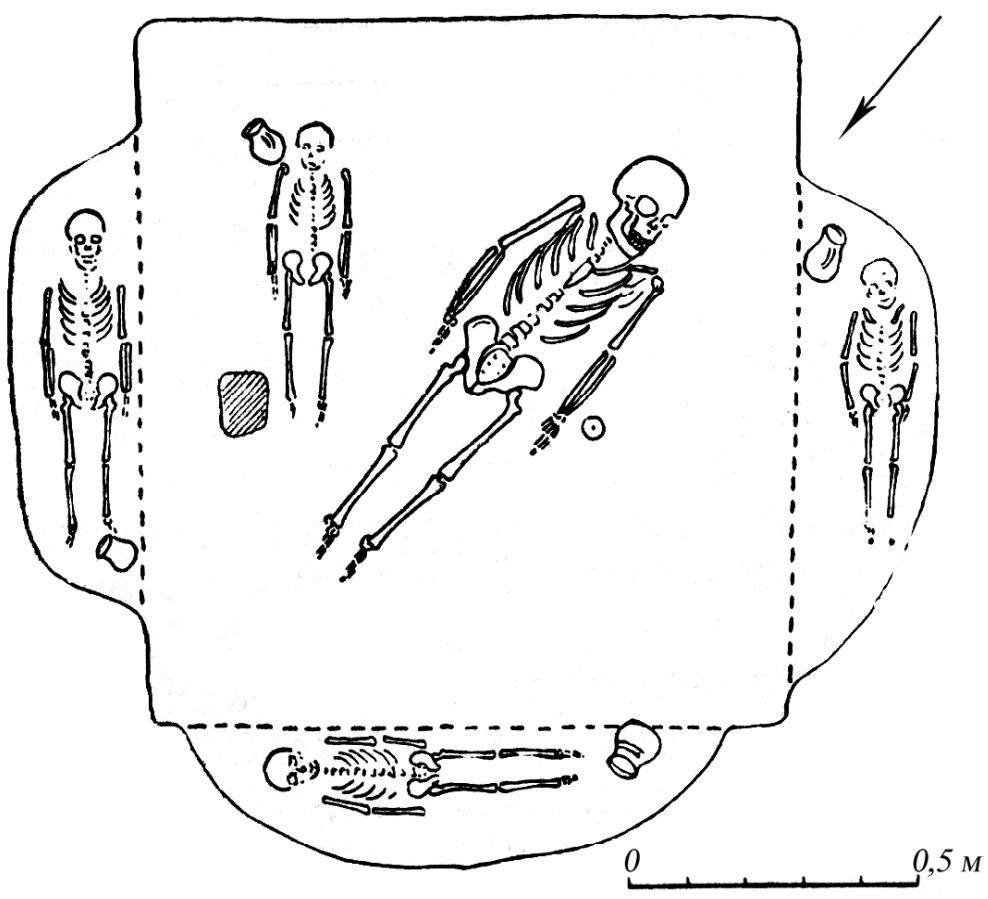

Рис. 4. Диагональное погребение среднесарматского времени из кургана 18 могильника Бережновка II

Fig. 4. Diagonal burial of the Middle Sarmatian time from barrow 18, Berezhnovka II 


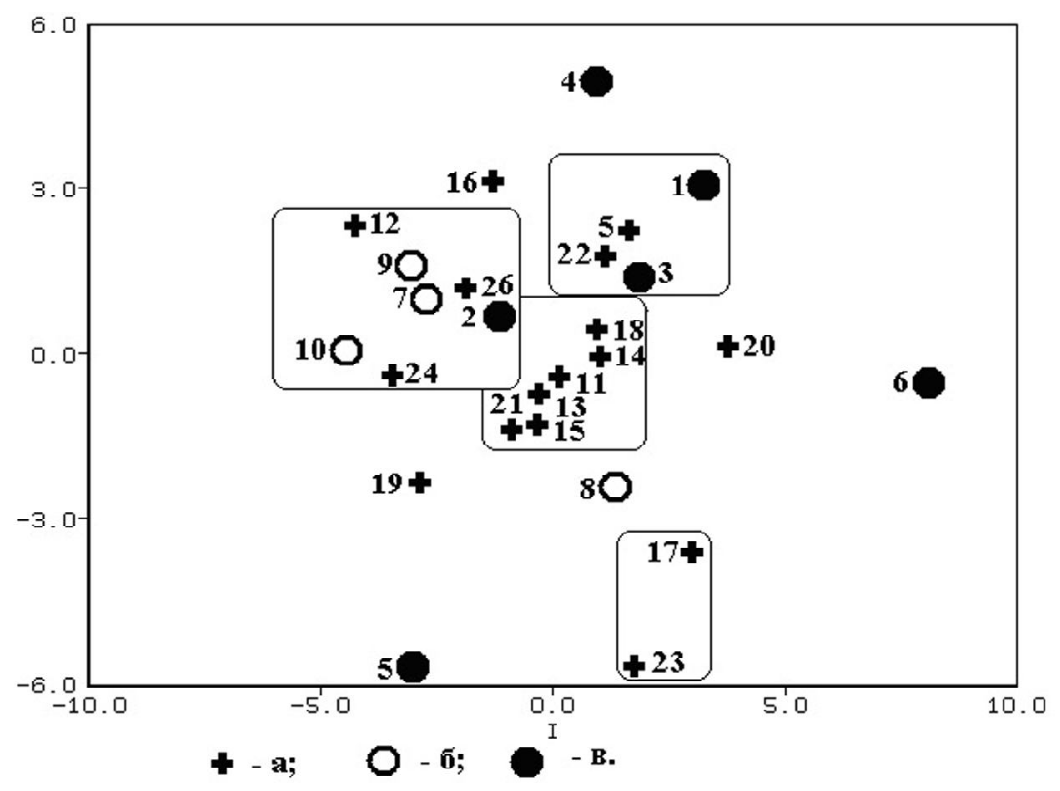

Рис. 5. Результат многомерного неметрического шкалирования и кластерного анализа матрицы внутригрупповых корреляций краниологической мужской серии из диагональных комплексов:

$a$ - черепа из погребений среднесарматского времени; $\sigma$ - черепа без деформации из погребений позднесарматского времени; в - черепа со следами искусственной деформации из погребений позднесарматского времени; объединены позиции, образующие один кластер

Fig. 5. The result of non-metric multidimensional scaling and cluster analysis of the matrix of intra-group correlations of the craniological male series from diagonal burial complexes:

Legend: $a$ - skulls from burials of the Middle Sarmatian time; $b$-skulls without deformation from the burials of the Late Sarmatian time; $c$ - skulls with signs of artificial deformation from the burials of the Late Sarmatian time; series forming one cluster are united

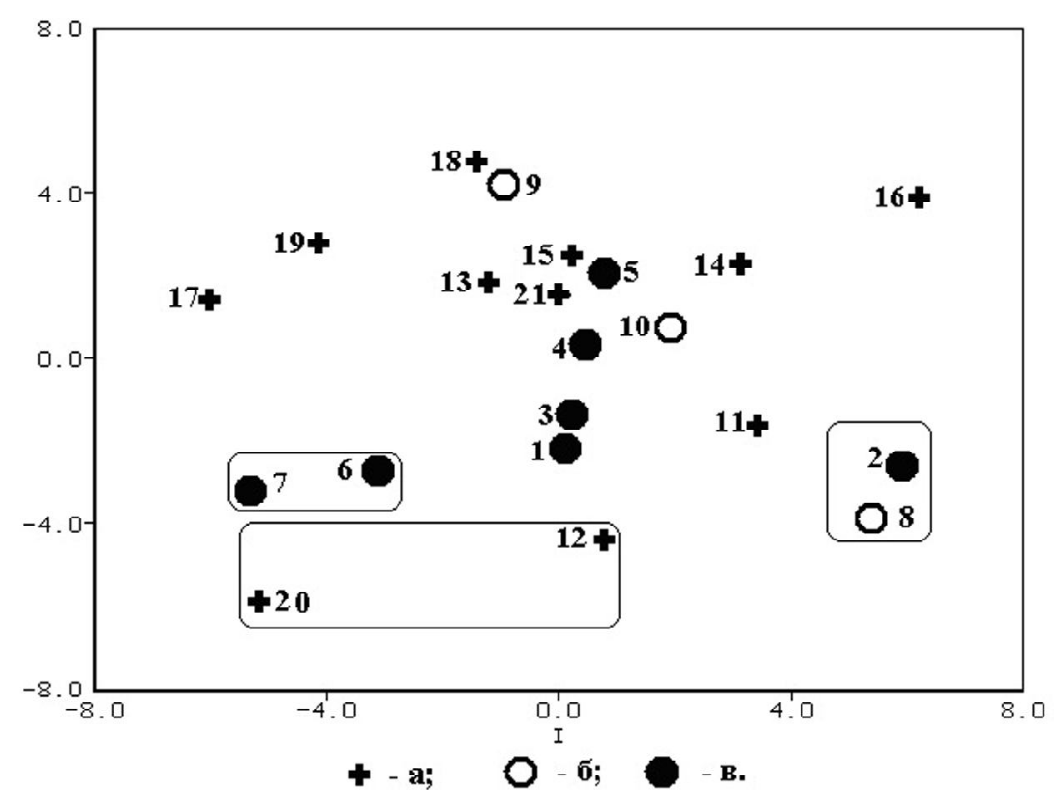

Рис. 6. Результат многомерного неметрического шкалирования и кластерного анализа матрицы внутригрупповых корреляций краниологической женской серии из диагональных комплексов (обозначения на рис. 5 и 6 совпадают)

Fig. 6. The result of a non-metric multidimensional scaling and cluster analysis of the matrix of intragroup correlations of the craniological female series from diagonal burials

(descriptions in Fig. 5 and Fig. 6 coincide) 


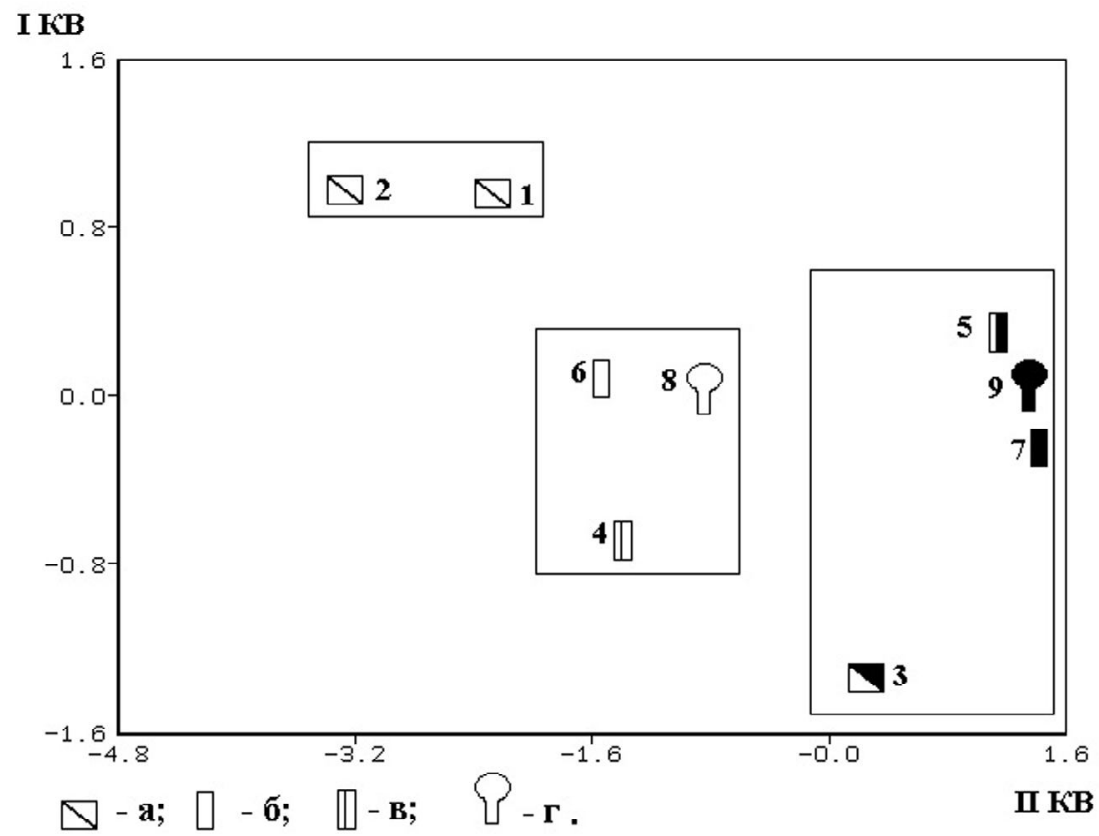

Рис. 7. Результат многомерного неметрического шкалирования и кластерного анализа расстояний близости по Махаланобису $\left(\mathrm{D}^{2}\right)$ мужских краниологических групп, образованных по типу погребальной конструкции:

$a$ - диагональный тип захоронения; $\sigma$ - узкая прямоугольная яма; в - узкие подбойные могилы; 2 - катакомбный тип захоронения. На рисунке: 1) заштрихованы значки, обозначающие серии

деформированных черепов; 2) объединены серии, образующие один кластер; 1 - серия из диагональных захоронений среднесарматского времени; 2 - серия недеформированных черепов из диагональных захоронений позднесарматского времени; 3 - серия деформированных черепов из диагональных захоронений позднесарматского времени; 4 - серия недеформированных черепов из подбойных захоронений позднесарматского времени; 5 - серия деформированных черепов из подбойных захоронений позднесарматского времени; 6 - серия недеформированных черепов из узких прямоугольных ям позднесарматского времени; 7 - серия деформированных черепов из узких прямоугольных ям позднесарматского времени; 8 - серия недеформированных черепов из катакомбных захоронений позднесарматского времени; 9 - серия деформированных черепов из катакомбных захоронений позднесарматского времени

Fig. 7. The result of a non-metric multidimensional scaling and cluster analysis of the Mahalanobis distance $\left(\mathrm{D}^{2}\right)$ of male craniological groups classified by the burial structure type:

$a$ - diagonal type of burial; $b$ - narrow rectangular pit; $c$ - narrow recess graves; $d$ - catacomb construction of the grave.

1) shaded icons showing the series of deformed skulls;2) the series forming one cluster are united;

1 - a series from the diagonal burials of the Middle Sarmatian time; 2 - a series of unstrained skulls from the diagonal burials of the Late Sarmatian time; 3 - a series of deformed skulls from diagonal burials of the Late Sarmatian time;

4 - a series of unstrained skulls from the recess graves of the Late Sarmatian time; 5 - a series of deformed skulls from the recess burials of the Late Sarmatian time; 6 - a series of unstrained skulls from the narrow rectangular pits of Late Sarmatian time; 7 - a series of deformed skulls from the narrow rectangular pits of the Late Sarmatian time; 8 - a series of unstrained skulls from the catacomb burials of the Late Sarmatian time; 9 - a series of deformed skulls from the catacomb burials of the Late Sarmatian time 
M.A. Balabanova, M.V. Krivosheev. Diagonal Burials as a Marker of Succession of Sarmatian Cultures

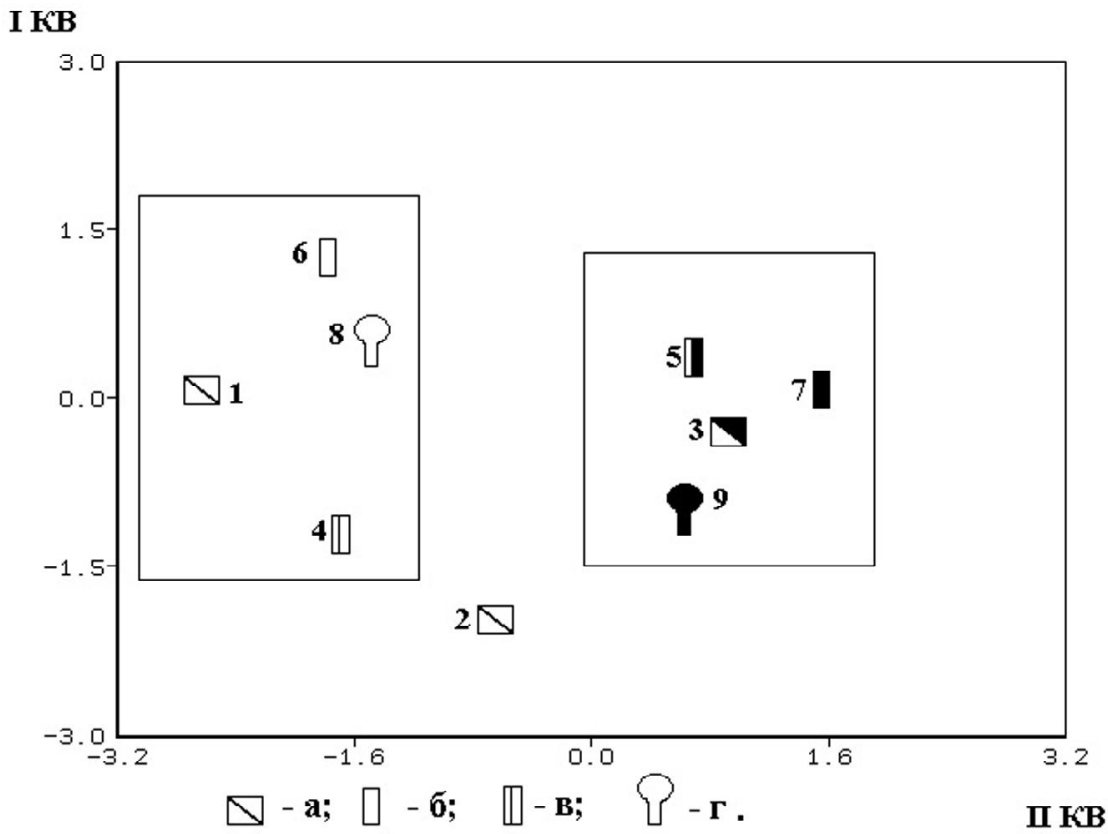

Рис. 8. Результат многомерного неметрического шкалирования и кластерного анализа расстояний близости по Махаланобису $\left(\mathrm{D}^{2}\right)$ женских краниологических групп, образованных по типу погребальной конструкции (обозначения на рис. 8 и 7 совпадают)

Fig. 8. The result of a non-metric multidimensional scaling and cluster analysis of the Mahalanobis distance $\left(\mathrm{D}^{2}\right)$ of female craniological groups classified by the burial structure type (descriptions in Fig. 8 and Fig. 7 coincide) 


\section{ПРИМЕЧАНИЕ}

${ }^{1}$ Исследование выполнено при финансовой поддержке Российского фонда фундаментальных исследований и Администрации Волгоградской области, проект «Преемственность и трансформация в развитии культур раннего железного века Нижнего Поволжья по данным археологии, палеоантропологии, палеоэкологии и палеогенетики», грант № 17-11-34006.

\section{СПИСОК ЛИТЕРАТУРЫ}

Абрамова М. П., 1959. Сарматская культура II в. до н.э. - I в. н.э. (по материалам Нижнего Поволжья. Сусловский этап) // Советская археология. № 1. С. 52-71.

Балабанова М. А., 2000. Антропология древнего населения Южного Приуралья и Нижнего Поволжья. Ранний железный век. М. : Наука. 133 с., ил.

Балабанова М. А., 2002. Антропология сарматских диагональных погребальных комплексов // Нижневолжский археологический вестник. Вып. 5. С. 82-94.

Глухов А. А., 2001. Сарматы междуречья Волги и Дона в I - первой половине II в. н.э. : дис. ... канд. ист. наук : 07.00.06. Волгоград. 384 с., ил.

Глухов А. А., 2005. Сарматы междуречья Волги и Дона в I- первой половине II в. н.э. Волгоград : Волгогр. науч. изд-во. 240 с.

Граков Б. Н., 1964. Рец. на кн.: В.Б. Виноградов. Сарматы Северо-Восточного Кавказа. Труды Чечено-Ингушского научно-исследовательского института, т. VI. Грозный, 1963. 178 с. + 48 табл. и рис. // Советская археология. № 4. С. 237-240.

Гущина И. П., Фирсов К. Б., 2000. Курганы у деревни Машевки, колонии Норка и станции Лебяжье в Балашовском и Камышинском уездах бывшей Саратовской губернии (по материалам раскопок А.А. Спицына в 1895 г.) // Нижневолжский археологический вестник. Вып. 3. С. 268-293.

Гутнов Ф. Х., 2001. Ранние аланы. Проблемы этносоциальной истории. Владикавказ : ИР. 256 с.

Железчиков Б. Ф., 1994. Общая характеристика исходных признаков погребального обряда савроматского времени // Статистическая обработка погребальных памятников Азиатской Сарматии. Вып. I : Савроматская эпоха (VIIV вв. до н.э.). М. С. 127-152.

Железчиков Б. Ф., 1997. Анализ сарматских погребальных памятников в IV-III вв. до н.э. // Статистическая обработка погребальных памят- ников Азиатской Сарматии. Вып. II. Раннесарматская культура. М. С. 46-130.

Засецкая И. П., 1974. «Диагональные» погребения Нижнего Поволжья и проблема определения их этнической принадлежности // Археологический сборник Государственного Эрмитажа. Вып. 16. Л. : Аврора. С. 105-121.

Клепиков В. М., Дьяченко А. Н., Блохин В. Г., Кривошеев М. В., 2006. Исследования курганов у сел Племхоз и Моисеево // Материалы по археологии Волго-Донских степей. Вып. 3. Волгоград : Изд-во ВолГУ. С. 164-190.

Копылов В. П., Кузнецов В. В., Янгулов С. Ю., 1990. Исследования экспедиции РГПИ в Багаевском районе Ростовской области в 1989 г. // Историко-археологические исследования в г. Азове и на Нижнем Донув 1989 г. Вып. 9. Азов. С. 17-22.

Костенко В. И., 1993. Сарматы в Нижнем Поднепровье. По материалам Усть-Каменского могильника. Дніпропетровськ : Видавництво ДДУ. $152 \mathrm{c}$.

Кривошеев М. В., 2004. О хронологии позднесарматских зеркал с центральной петелькой // Проблемы археологии Нижнего Поволжья : I Междунар. Нижневолж. археол. конф. : тез. докл. Волгоград : Изд-во ВолГУ. С. 238-242.

Кривошеев М. В., 2005. Позднесарматская культура южной части междуречья Волги и Дона. Проблемы хронологии и периодизации : дис. ... канд. ист. наук : 07.00.06. Волгоград. 336 с.

Кривошеев М. В., 2010. Вопросы происхождения и развития позднесарматской культуры в Нижнем Поволжье // Становление и развитие позднесарматской культуры (по археологическим и естественнонаучным данным) : материалы семинара Центра изучения истории и культуры сарматов. Вып. III. Волгоград : Изд-во ВолГУ. С. 57-92.

Кривошеев М. В., 2013. Скифо-сарматские параллели. Новые данные // Шестая Международная Кубанская археологическая конференция : материалы конф. Краснодар : Экоинвест. C. $210-213$.

Кривошеев М. В., 2016. Ножницы в погребальном обряде сарматов // Константин Федорович Смирнов и современные проблемы сарматской археологии : материалы IX Междунар. науч. конф. «Проблемы сарматской археологии и истории», посвящ. 100-летию со дня рождения Константина Федоровича Смирнова : сб. ст. Оренбург : Изд-во ОГПУ. С. 122-131.

Кривошеев М. В., Скрипкин А. С., 2011. Формирование и развитие позднесарматской культуры в Нижнем Поволжье (по данным погребального обряда) // Погребальный обряд ранних кочевников Евразии : материалы VII Меж- 
дунар. науч. конф. (11-15 мая 2011 г., г. Ростов-на-Дону, Кагальник). Ростов н/Д : Изд-во ЮНЦ РАН. С. 75-85.

Максимов Е. К., 1966. Сарматские диагональные погребения Восточной Европы // Археологический сборник. Саратов : Изд-во СГУ. C. 98-115.

Малашев В. Ю., 2000. Периодизация ременных гарнитур позднесарматского времени // Сарматы и их соседи на Дону. Ростов н/Д : Терра. C. 194-232.

Малашев В. Ю., 2013. Позднесарматская культура Южного Приуралья во II-III вв. н.э. : дис. ... канд. ист. наук : 07.00.06. М. 301 с.

Мошкова М. Г., 2004а. Среднесарматские и позднесарматские памятники на территории Южного Приуралья // Сарматские культуры Евразии: проблемы региональной хронологии : докл. к V Междунар. конф. «Проблемы сарматской археологии и истории». Краснодар : Фирма НСС. С. 22-44.

Мошкова М. Г., 2004б. О времени существования диагональных погребений на территории Южного Приуралья // Археологические памятники раннего железного века Юга России. M. C. $147-165$.

Мошкова М. Г., 2009. Анализ сарматских погребальных памятников II-IV вв. н.э. // Статистическая обработка погребальных памятников Азиатской Сарматии. Вып. IV. Позднесарматская культура. М. : Вост. лит. 176 с.

Перерва Е. В., 2011. Патология населения, оставившего диагональные археологические комплексы (по антропологическим материалам из среднесарматских погребений) // Погребальный обряд ранних кочевников Евразии : материалы VII Междунар. науч. конф. «Проблемы сарматской археологии и истории» (1115 мая 2011 г., г. Ростов-на-Дону, Кагальник). Ростов н/Д : Изд-во ЮНЦ РАН. С. 201-205.

Сергацков И. В., 2000. Сарматские курганы на Иловле. Волгоград : Изд-во ВолГУ. 397 с.

Сергацков И. В., 2002. Анализ сарматских погребальных памятников в I-II вв. н.э. // Статистическая обработка погребальных памятников Азиатской Сарматии. Вып. III. Среднесарматская культура. М. : Вост. лит. С. 22-129.

Синицын И. В., 1960. Древние памятники в низовьях Еруслана // Материалы и исследования по археологии СССР. № 78. Т. II. М. : Изд-во АН CССР. С. $10-168$.

Скрипкин А. С., 1973. Раскопки курганов на Иловле // Историко-краеведческие записки. Вып. 1. Волгоград : Нижневолж. кн. изд-во. С. 95-109.

Скрипкин А. С., 1981. К проблеме хронологии археологических памятников Азиатской Сарматии
II-IV вв. // Древние и средневековые культуры Поволжья. Куйбышев. С. 73-87.

Скрипкин А. С., 1984. Нижнее Поволжье в первые века нашей эры. Саратов : Изд-во СГУ. 150 с.

Скрипкин А. С., 1988. Азиатская Сарматия: проблемы истории и культуры // Проблемы сарматской археологии и истории : тез. докл. конф. Азов. С. 118-132.

Скрипкин А. С., 1990. Азиатская Сарматия. Проблемы хронологии и ее исторический аспект. Саратов : Изд-во Сарат. ун-та. 299 с.

Скрипкин А. С., 1992. Азиатская Сарматия. Проблемы хронологии, периодизации и этнополитической истории : науч. докл., представленный в качестве диссертации на соискание ученой степени доктора исторических наук. M. $46 \mathrm{c}$.

Скрипкин А. С., 1996. К вопросу о этнической истории сарматов первых веков нашей эры // Вестник древней истории. № 1. С. 160-169.

Скрипкин А. С., 1997а. Этюды по истории и культуре сарматов. Волгоград : Изд-во ВолГУ. 104 с.

Скрипкин А. С., 1997б. Анализ сарматских погребальных памятников III-I вв. до н.э. // Статистическая обработка погребальных памятников Азиатской Сарматии. Вып. II. Раннесарматская культура (IV-I вв. до н.э.). М. C. 131-212.

Смирнов К. Ф., 1948. О погребениях роксолан // Вестник древней истории. № 1. С. 213-219.

Смирнов К. Ф., 1959. Курганы у сел Иловатка и Политотдельское Сталинградской области // Материалы и исследования по археологии СССР. № 60. T. I. М. : Изд-во АН СССР. С. 206-322.

Смирнов К. Ф., 1974. Сарматы Нижнего Поволжья и междуречья Дона и Волги в IV в. до н.э. II в. н.э. (историко-археологический очерк) // Советская археология. № 3. С. 33-44.

Фирштейн Б. В., 1970. Сарматы Нижнего Поволжья в антропологическом освещении // Тот Т. А., Фирштейн Б. В. Антропологические данные к вопросу о великом переселении народов. Авары и сарматы. Л. : Наука. С. 69-201.

Шилов В. П., 1959. Калиновский курганный могильник // Материалы и исследования по археологии СССР. № 60. Т. І. М. : Изд-во АН СССР. C. $323-523$.

\section{REFERENSES}

Abramova M.P., 1959. The Sarmatian culture of the $2^{\text {nd }}$ century BC. - I century AD (based on materials from the Lower Volga region. Suslovsky stage). Sovetskaja arheologiya, no. 1, pp. 5271. (in Russian). 
Balabanova M.A., 2000. Anthropology of the ancient population of the Southern Urals and the Lower Volga region. Early Iron age. Moscow, Nauka Publ. 133 p. (in Russian).

Balabanova M.A., 2002. Anthropology of diagonal sarmatian complexes. The Lower Volga Archaeological Bulletin, iss. 5, pp. 82-94. (in Russian).

Gluhov A.A., 2001. Sarmatians between the rivers of the Volga and the Don in the I-first half of the II cc. AD. Cand. hist. sci. diss. Volgograd. 384 p. (in Russian).

Gluhov A.A., 2005. Sarmatians between the rivers of the Volga and the Don in the I-first half of the II cc. AD. Volgograd, Volgograd. sci. publishing house. 240 p. (in Russian).

Grakov B.N., 1964. Review on the book: V.B. Vinogradov. Sarmatians of the NorthEastern Caucasus. Proceedings of the ChechenIngush Research Institute. Vol. VI. Grozny, 1963, 178 p. +48 tab. and drawings. Sovetskaja arheologiya, no. 4, pp. 237-240. (in Russian).

Guschina I.I., Firsov K.B., 2000. Barrows near the village Mashevka, the colony Norka, and the station Lebyazhye in Balashov and Kamyshin uyezd of the former Saratovskaya guberniya (after excavation materials by A.A. Spitsin in 1895). The Lower Volga Archaeological Bulletin, iss. 3, pp. 268-293. (in Russian).

Gutnov F.Kh., 2001. Early Alans. Problems of ethnosocial history. Vladikavkaz, IR Publ. 256 p. (in Russian).

Zhelezchikov B.F., 1994. General characteristics of initial signs of funeral rite of the Sauromatian time. Statisticheskaya obrabotka pogrebalnykh pamyatnikov Aziatskoy Sarmatii. Vyp. I. Savromatskaja jepoha (VI-IVvv. do n.e.). Moscow, pp. 127-152. (in Russian).

Zhelezchikov B.F., 1997. Analysis of Sarmatian burial monuments in the IV-III centuries BC. Statisticheskaya obrabotka pogrebalnykh pamyatnikov Aziatskoy Sarmatii. Vyp. II. Rannesarmatskaya kultura (IV-I vv. do n.e.). Moscow, pp. 46-130. (in Russian).

Zasetskaya I.P., 1974. "Diagonal" burials of the Lower Volga region and the problem of determining their ethnicity. Arheologicheskij sbornik Gosudarstvennogo Ermitazha, iss. 16. Leningrad, Avrora Publ., pp. 105-121. (in Russian).

Klepikov V.M., Dyachenko A.N., Blokhin V.G., Krivosheev M.V., 2006. Study the mounds near the villages Plemkhoz and Moiseevo. Materialy po arheologii Volgo-Donskih stepej, iss. 3. Volgograd, Publishing house of Volgograd State University, pp.164-190. (in Russian).
Kopylov V.P., Kuznetsov V.V., Yangulov S.Yu., 1990. Investigations of the expedition of the Russian State Pedagogical Institute in the Bagaevsky district of the Rostov region in 1989. Istorikoarheologicheskie issledovanija $v$ g. Azove i na Nizhnem Donu v 1989 g., iss. 9. Azov, pp. 17-22. (in Russian).

Kostenko V. I., 1993. Sarmatians in the Lower Dnieper. On materials of Ust-Kamenka cemetery. Dnepropetrovsk, Publishing house of the Dnipropetrovsk state University. 152 p. (in Russian).

Krivosheev M.V., 2004. About the chronology of the Late Sarmatian mirrors with a central loop. Problemy arheologii Nizhnego Povolzh'ja: I Mezhdunar. Nizhnevolzh. arheol. konf.: tez. dokl. Volgograd, Publishing house of Volgograd State University, pp. 238-242. (in Russian).

Krivosheev M.V., 2005. Late Sarmatian culture in the southern part of the interfluve of the Volga and the Don. Problems of chronology and periodization. Cand. hist. sci. diss. Volgograd. 336 p. (in Russian).

Krivosheev M.V., 2010. Questions of origin and development of the Late Sarmatian culture in the Lower Volga region. Stanovlenie $i$ razvitie pozdnesarmatskoj kul tury (po arheologicheskim $i$ estestvennonauchnym dannym). Volgograd, Publishing house of Volgograd State University, pp. 57-92. (in Russian).

Krivosheev M.V., 2013. Scythian-Sarmatian parallels. New evidence. Shestaja Mezhdunarodnaja Kubanskaja arheologicheskaja konferencija: materialy konf. Krasnodar, Ecoinvest Publ., pp. 210-213. (in Russian).

Krivosheev M.V., 2016. Shears in burial rite of the Sarmatians. Konstantin Fedorovich Smirnov $i$ sovremennye problemy sarmatskoj arheologii. Orenburg, Publishing house of Orenburg State Pedagogical University, pp. 122-131. (in Russian).

Krivosheev M.V., Skripkin A.S., 2011. The formation and development of the Late Sarmatian culture in the Lower Volga region (according to the funeral rite). Pogrebal'nyj obrjad rannih kochevnikov Evrazii: materialy VII Mezhdunar. nauch. konf. (11-15 maja 2011 g., Rostov-naDonu, Kagal'nik). Rostov-on-Don, PublishingHouse of the SSC RAS, pp. 75-85. (in Russian).

Maksimov E.K., 1966. Sarmatian diagonal burials of Eastern Europe Arheologicheskiy sbornik. Saratov, Publishing house of Saratov State University, pp. 98-115. (in Russian).

Malashev V.Yu., 2000. Periodizations of Belt Fittings of Late Sarmatian Time. Sarmaty $i$ ih sosedi na Donu. Rostov-on-Don, Terra Publ., pp. 194-232. (in Russian). 
Malashev V.Yu., 2013. The Late Sarmatian Culture of the Southern Urals in the $2^{\text {nd }}-3^{\text {rd }}$ Centuries AD. Cand. hist. sci. diss. Moscow. 301 p. (in Russian).

Moshkova M.G., 2004a. Middle Sarmatian and Late Sarmatian monuments in the territory of the Southern Urals. Sarmatskie kul'tury Evrazii: problemy regional'noj hronologii: dokl. $k$ V Mezhdunar. konf. "Problemy sarmatskoj arheologii $i$ istorii». Krasnodar, NSS Publ., pp. 22-44. (in Russian).

Moshkova M.G., 20046. About the time of existence of diagonal burials in the territory of the Southern Urals. Arheologicheskie pamjatniki rannego zheleznogo veka Juga Rossii. Moscow, pp. 147-165. (in Russian).

Moshkova M.G., 2009. Analysis of Sarmatian Burial Monuments of the $2^{\text {nd }}-4^{\text {th }}$ Centuries A.D. Statisticheskaya obrabotka pogrebalnykh pamyatnikov Aziatskoy Sarmatii. Vyp. IV. Pozdnesarmatskaya kultura. Moscow, Vostochnaya literatura Publ. 176 p. (in Russian).

Pererva E.V., 2011. Pathology of the population who left diagonal archaeological complexes (based on anthropological materials from the Middle Sarmatian burials). Pogrebal'nyj obrjad rannih kochevnikov Evrazii: materialy VII Mezhdunar. nauch. konf. (11-15 maja 2011 g., g. Rostovna-Donu, Kagal'nik). Rostov-on-Don, Publishing-House of the SSC RAS, pp. 201-205.

Sergatskov I.V., 2000. Sarmatian burial mounds on Ilovlya river. Volgograd, Publishing house of Volgograd State University. 396 p. (in Russian).

Sergatskov I.V., 2002. Analysis of Sarmatian Burial Monuments of the $1^{\text {st }}-2^{\text {nd }}$ Centuries A.D. Statisticheskaya obrabotka pogrebalnykh pamyatnikov Aziatskoy Sarmatii. Vyp. III. Srednesarmatskaya kultura. Moscow, Vostochnaya literatura Publ., pp. 22-129. (in Russian).

Sinitsyn I. V., 1960. Ancient monuments in the lower reaches of Eruslan. Materialy $i$ issledovanija po arheologii SSSR, no. 78, vol. II. Moscow, Publishing house of the Academy of Sciences of the USSR, pp. 10-168. (in Russian).

Skripkin A.S., 1973. Excavations of mounds on the Ilovlya river. Istoriko-kraevedcheskie zapiski. Vyp. I. Volgograd, Lower Volga Book Publishing House, pp. 95-109. (in Russian).

Skripkin A.S., 1981. To the problem of the chronology of archaeological monuments of Asian Sarmatia of the II-IV cc. Drevnie i srednevekovye kul tury Povolzh'ja. Kujbyshev, pp. 73-87. (in Russian).
Skripkin A.S., 1984. Lower Volga region in the first centuries of our era. Saratov, Publishing house of Saratov State University. 150 p. (in Russian).

Skripkin A.S., 1988. Asian Sarmatia: Problems of History and Culture. Problemy sarmatskoj arheologii i istorii: tez. dokl. konf. Azov, pp. 118-132. (in Russian).

Skripkin A.S., 1990. Asian Sarmatia. Problems of chronology and its historical aspect. Saratov, Publishing house of Saratov University. 299 p. (in Russian).

Skripkin A.S., 1992. Asian Sarmatia. Problems of chronology, periodization and ethnopolitical history. A scientific report presented as a thesis for the degree of Doctor of Historical Sciences. Moscow. 46 p. (in Russian).

Skripkin A.S., 1996. To the Question of Ethnic History of Sarmatians of the First Centuries AD. Journal of Ancient History, no. 1, pp. 160-169. (in Russian).

Skripkin A.S., 1997a. Etudes on the History and Culture of the Sarmatians. Volgograd, Publishing house of Volgograd State University. 104 p. (in Russian).

Skripkin A.S., 1997б. Analysis of Sarmatian Burial Monuments of the $3^{\text {nd }}-1^{\text {st }}$ Centuries B.C. Statisticheskaya obrabotka pogrebalnykh pamyatnikov Aziatskoy Sarmatii. Vyp. II. Rannesarmatskaya kultura (IV-I vv. do n.e.). Moscow, pp. 131-212. (in Russian).

Smirnov K.F., 1948. About burials of Roxolans. Journal of Ancient History, no. 1, pp. 213-219. (in Russian).

Smirnov K.F., 1959. Burial Mounds Nearthe Ilovatka and Politotdelskoe Villages in the Stalingrad Region. Materialy i issledovanija po arheologii SSSR, no. 60 (1). Moscow, Publishing house of the Academy of Sciences of the USSR, pp. 206322. (in Russian).

Smirnov K.F., 1974. The Sarmatians of the Lower Volga region and the Don and the Volga interfluve, in the IV century BC - II century AD (historicalarcheological essay). Sovetskaja arheologiya, no. 3, pp. 33-44. (in Russian).

Firshteyn B.V., 1970. Sarmatians of the Lower Volga region (anthropological aspect). Tot T.A., Firshteyn B.V. Antropologicheskie dannye $k$ voprosu o velikom pereselenii narodov. Avary i sarmaty. Leningrad, Nauka Publ., pp. 69-201. (in Russian).

Shilov V.P., 1959. Kalinovsky kurgan cemetery. Materialy i issledovanija po arheologii SSSR, no. 60 (1). Moscow, Publishing house of the Academy of Sciences of the USSR, pp. 323-523. (in Russian). 
М.А. Балабанова, М.В. Кривошеев. Диагональные погребения как маркер преемственности в сарматских культурах

\section{Information about the Authors}

Mariya A. Balabanova, Doctor of Sciences (History), Professor, Department of Russian and Foreign History, Archaeology, Volgograd State University, Prosp. Universitetsky, 100, 400062 Volgograd, Russian Federation, mary.balabanova@volsu.ru.

Mikhail V. Krivosheev, Candidate of Sciences (History), Head of Laboratory of Archaeological Research, Volgograd State University, Prosp. Universitetsky, 100, 400062 Volgograd, Russian Federation, arhlab@volsu.ru,tyaf@mail.ru.

\section{Информация об авторах}

Мария Афанасьевна Балабанова, доктор исторических наук, профессор кафедры отечественной и зарубежной истории, археологии, Волгоградский государственный университет, просп. Университетский, 100, 400062 г. Волгоград, Российская Федерация, mary.balabanova@volsu.ru.

Михаил Васильевич Кривошеев, кандидат исторических наук, заведующий лабораторией археологических исследований, Волгоградский государственный университет, просп. Университетский, 100, 400062 г. Волгоград, Российская Федерация, arhlab@volsu.ru, tyaf@mail.ru. 